\title{
Palaeoecology and depositional environments of the Tendaguru Beds (Late Jurassic to Early Cretaceous, Tanzania)
}

\author{
Martin Aberhan $^{1}$, Robert Bussert ${ }^{2}$, Wolf-Dieter Heinrich ${ }^{1}$, Eckhart Schrank ${ }^{2}$, Stephan Schultka ${ }^{1}$, \\ Benjamin Sames $^{3}$, Jürgen Kriwet ${ }^{4}$ \& Saidi Kapilima ${ }^{5}$
}

With 6 figures, 2 tables, and 2 plates

\begin{abstract}
The Late Jurassic to Early Cretaceous Tendaguru Beds (Tanzania, East Africa) have been well known for nearly a century for their diverse dinosaur assemblages. Here, we present sedimentological and palaeontological data collected by the GermanTanzanian Tendaguru Expedition 2000 in an attempt to reconstruct the palaeo-ecosystems of the Tendaguru Beds at their type locality. Our reconstructions are based on sedimentological data and on a palaeoecological analysis of macroinvertebrates, microvertebrates, plant fossils and microfossils (ostracods, foraminifera, charophytes, palynomorphs). In addition, we included data from previous expeditions, particularly those on the dinosaur assemblages.

The environmental model of the Tendaguru Beds presented herein comprises three broad palaeoenvironmental units in a marginal marine setting: (1) Lagoon-like, shallow marine environments above fair weather wave base and with evidence of tides and storms. These formed behind barriers such as ooid bar and siliciclastic sand bar complexes and were generally subject to minor salinity fluctuations. (2) Extended tidal flats and low-relief coastal plains. These include low-energy, brackish coastal lakes and ponds as well as pools and small fluvial channels of coastal plains in which the large dinosaurs were buried. Since these environments apparently were, at best, poorly vegetated, the main feeding grounds of giant sauropods must have been elsewhere. Presumably, tidal flats and coastal plains were visited by dinosaurs primarily during periods of drought. (3) Vegetated hinterland. Vegetation of this environment can only be inferred indirectly from plant material transported into the other depositional environments. Vegetation was dominated by a diverse conifer flora, which apparently formed part of the food source of large herbivorous sauropods. Evidence from various sources suggests a subtropical to tropical palaeoclimate, characterised by seasonal rainfall alternating with a pronounced dry season during the Late Jurassic. In Early Cretaceous times, sedimentological and palaeontological proxies suggest a climatic shift towards more humid conditions.
\end{abstract}

Key words: Tendaguru, Tanzania, Mesozoic, Jurassic, sedimentology, palaeozoology, palaeobotany, palynology, palaeoecology, taphonomy, dinosaurs, climate

\section{Zusammenfassung}

Die Tendaguru-Schichten von Tansania in Ostafrika (Oberjura bis Unterkreide) sind als Lagerstätte oberjurassischer Dinosaurier seit nahezu einem Jahrhundert weltweit bekannt. Anhand von sedimentologischen und paläontologischen Daten, die während der Deutsch-Tansanischen Tendaguru Expedition 2000 im Typus-Gebiet der Tendaguru-Schichten gewonnen wurden, werden Paläo-Ökosysteme rekonstruiert. Grundlage der Rekonstruktionen sind die Auswertung sedimentologischer Daten sowie die paläo-ökologische Analyse von Makroinvertebraten, Mikrovertebraten, pflanzlichen Fossilien und Mikrofossilien (Ostrakoden, Foraminiferen, Charophyten, Palynomorphen). Darüber hinaus werden Informationen über Dinosaurier berücksichtigt, die bei früheren Expeditionen gewonnen wurden.

Das hier vorgestellte Ablagerungsmodell der Tendaguru-Schichten umfaßt drei Teilbereiche eines randlich marinen Sedimentationsraumes, die wie folgt gekennzeichnet werden können: (1) Lagunen-artige, marine Flachwasserbereiche, die oberhalb der Schönwetter-Wellenbasis lagen und unter deutlichem Einfluß von Gezeiten und Stürmen standen. Sie waren vom offenen Meer durch Barrieren, wie Ooidbarren und siliziklastischen Sandbarrenkomplexen, getrennt und wiesen einen leicht schwankenden Salzgehalt auf. (2) Ausgedehnte Wattgebiete und flache Küstenebenen. Dort befanden sich niedrig-energetische, brackische Strandseen und Teiche sowie Tümpel und kleinere Flußrinnen, in denen die großen Dinosaurier eingebettet wurden. Da diese Lebensräume bestenfalls dürftig bewachsen waren, müssen die Nahrungsquellen und der eigentliche Lebensraum der riesigen Sauropoden anderswo gelegen haben. Vermutlich wurden die Wattgebiete und Flachküsten von Dino-

1 Museum für Naturkunde, Zentralinstitut der Humboldt-Universität zu Berlin, Institut für Paläontologie, Invalidenstr. 43, D-10115 Berlin, Germany. E-mail: martin.aberhan@rt.hu-berlin.de

2 Institut für Angewandte Geowissenschaften, Technische Universität Berlin, Sekr. BH 2, Ernst-Reuter-Platz 1, D-10587 Berlin, Germany.

${ }^{3}$ Institut für Geologische Wissenschaften, Fachrichtung Paläontologie, Freie Universität Berlin, Malteserstr. 74-100, D-12249 Berlin, Germany.

${ }^{4}$ Department of Earth Sciences, University of Bristol, Queens Road, Bristol BS8 1RJ, United Kingdom.

5 Department of Geology, University of Dar es Salaam, P.O. Box 35052, Dar es Salaam, Tanzania.

Received March, accepted July 2002 
sauriern vorrangig in den Trockenzeiten aufgesucht. (3) Bewachsenes Hinterland. Die Vegetation dieses Lebensraumes kann nur indirekt aus Pflanzenresten erschlossen werden, die in die anderen Ablagerungsräume transportiert wurden. Die Vegetation wurde von einer diversen Koniferenflora dominiert, die zumindest teilweise die Nahrungsgrundlage der großen, herbivoren Sauropoden bildete. Sedimentologische und paläontologische Indikatoren sprechen für ein subtropisches bis tropisches Klima während der späten Jurazeit mit einem jahreszeitlichen Wechsel von Regenfällen und ausgeprägten Trockenzeiten. In der frühen Kreidezeit deutet sich ein Wechsel zu stärker humiden Bedingungen an.

Schlüsselwörter: Tendaguru, Tansania, Mesozoikum, Jura, Sedimentologie, Paläozoologie, Paläobotanik, Palynologie, Paläoökologie, Taphonomie, Dinosaurier, Klima

\section{Introduction}

The famous fossil locality of Tendaguru is located approximately 60 kilometers northwest of the seaport of Lindi in southeastern Tanzania. While the diverse Late Jurassic dinosaur assemblages of the Tendaguru Beds have attracted considerable scientific attention (e.g., Maier in press), many associated organisms such as microvertebrates, plants and microfossils (e.g., ostracods and palynomorphs) remain largely unknown. Only the Late Jurassic to Early Cretaceous macroinvertebrates (mainly molluscs and corals) are well documented in the literature (e.g., Hennig 1914a, Lange 1914, Zwierzycki 1914, Dietrich 1914, 1926, 1933, Cox 1965), and a quantitative palaeoecological analysis together with a modern sedimentological analysis of the Tendaguru Beds is still lacking.

In order to fill this gap in our understanding of the Tendaguru ecosystem, an expedition revisited Tendaguru in 2000 (Heinrich et al. 2001) with the aim of collecting new sedimentological and stratigraphical data, invertebrates, microvertebrates and plant fossils. In this paper, we combine sedimentological and palaeontological data in an attempt to reconstruct the environmental setting of the Tendaguru Beds at their type locality. For this purpose, the six lithostratigraphic units of the Tendaguru Beds were analysed separately so that stratigraphically less constrained information from former expeditions, particularly the German Tendaguru Expedition (1909-1913, GTE) could be included. For each unit, we present a brief outline of the overall lithology and sedimentary structures, followed by a description of the macroinvertebrates and calcareous microfossils, macro- and microvertebrates, and mesoand palynoflora. This information is utilized for environmental and palaeoecological interpretations of the various litho- and biofacies. Finally, an attempt was made to develop an integrated environmental model of the Tendaguru Beds in the light of these new results.

\section{Geological setting and study area}

The Tendaguru area is situated in the southwest of the Mandawa Basin, a coastal basin forming the southwestern part of the Somali Basin. The Masasi Basement Complex marks the western boundary of the Mandawa Basin. To the south, a basement uplift separates this basin from the $\mathrm{Ru}$ vuma Basin, while the northern boundary is formed by the Rufiji Basin (TPDC 1995).

The Mesozoic sediments of the Mandawa Basin record plate tectonic processes related to the break-up of Gondwana. During the Permo-Triassic, far-field stresses associated with the Gondwanide orogeny promoted the reactivation of preexisting fracture systems and the development of the intracratonal Karoo rifts (Visser \& Praekelt 1996, Trouw \& De Wit 1999). The Early Jurassic continental siliciclastic sediments of the Mandawa Basin indicate the presence of at least the youngest part of the Karoo system (Balduzzi et al. 1992).

Subsequently, the onset of sea-floor spreading in the Somali basin and the initial disintegration of Gondwana during the Middle Jurassic resulted in a break-up unconformity (Kreuser 1995) and in a marine transgression that reached the Mandawa Basin from the north. The basin developed into a passive continental margin and entered a sag phase. During the Late Jurassic, a northeast dipping continental to shallow marine ramp setting was established, with a mixed carbonate-siliciclastic sedimentation that probably continued until the Valanginian - Hauterivian. The cyclic character of the Late Jurassic to early Early Cretaceous sediments suggests control by sea-level changes. In Early Cretaceous times, an unconformity developed in response to a widespread phase of regression and uplift that might be related to the end of spreading in the Somali Basin (Coffin \& Rabinowitz 1988) and/or the onset of separation between Madagascar/India, Australia and Antarctica (Powell et al. 1988). In the late Early Cretaceous, deposition continued with fluvial to shallow marine siliciclastic sediments of the Makonde Formation. 


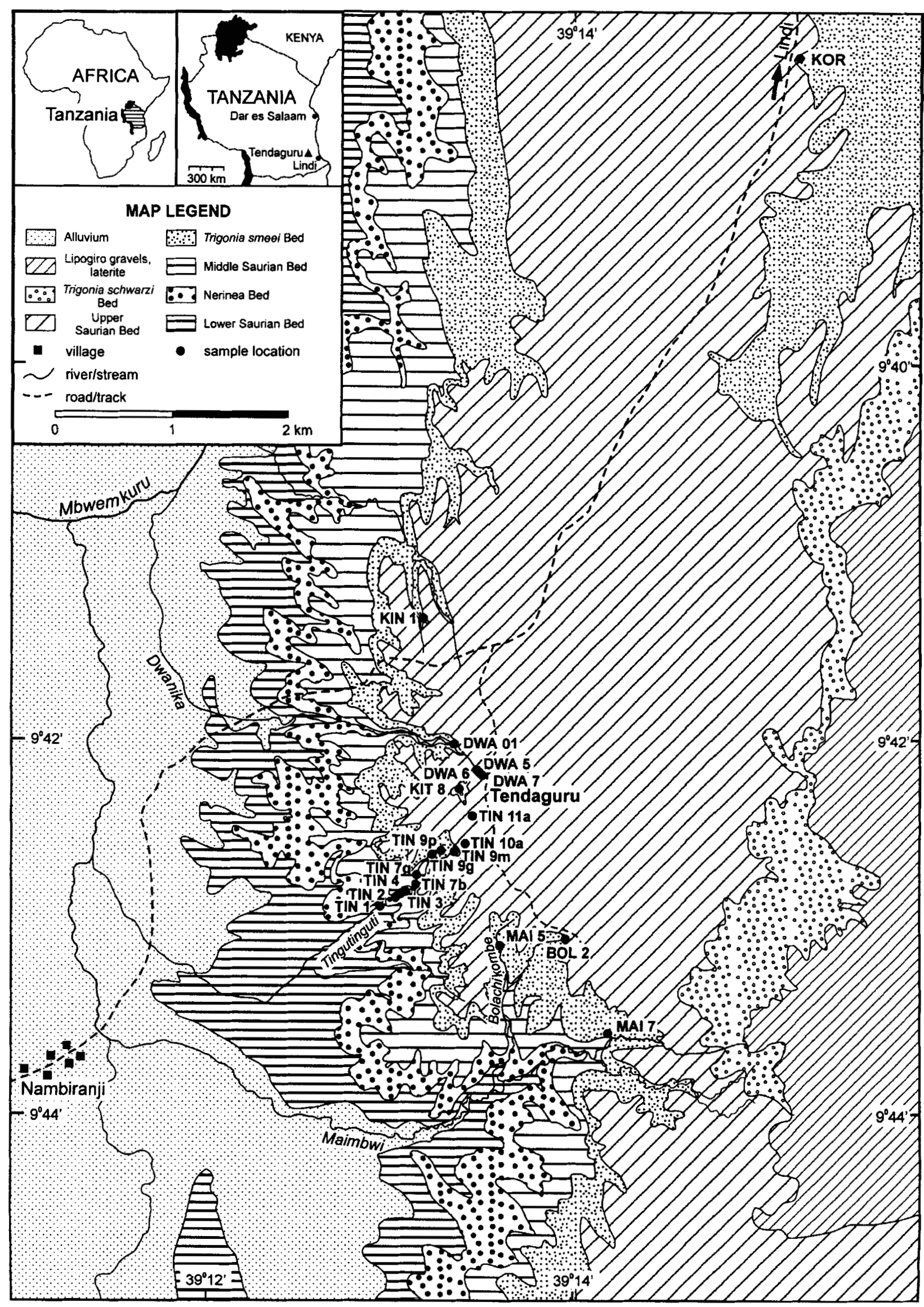

Fig. 1. Geological map of the Tendaguru area with location of profiles and samples. Bol: Bolachikombe; Dwa: Dwanika; Kin Kindope; Kit: Kitukituki; Kor: coral locality; Mai: Maimbwi; Tin: Tingutinguti. Based on Hennig (1914a), Janensch (1914a, b, 1925a) and new data of the German-Tanzanian Tendaguru Expedition 2000. 


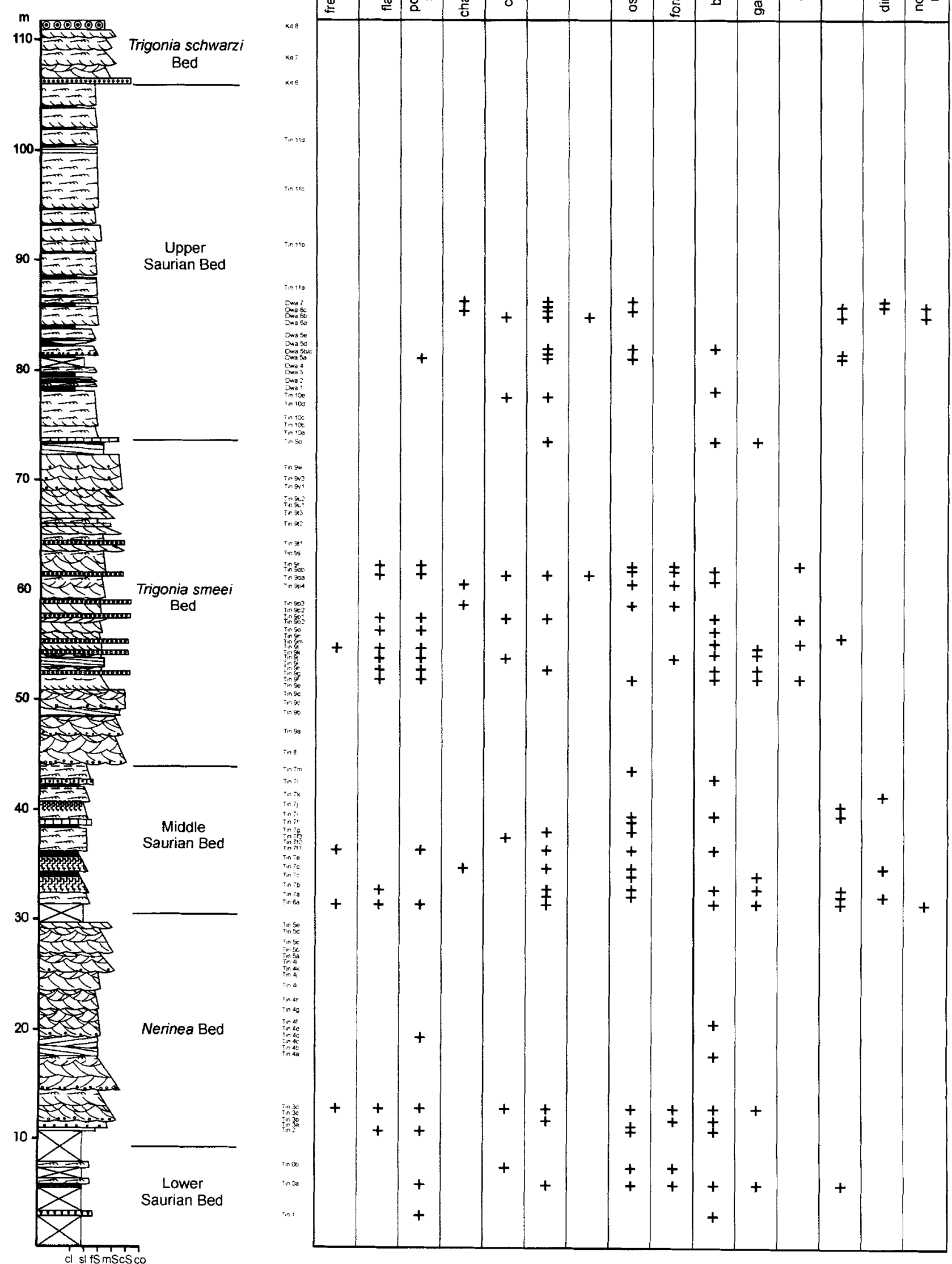


In the Paleogene and Neogene, the western part of the Mandawa Basin experienced several phases of uplift, whereas the eastern part continued to subside (Kent et al. 1971). Finally, tilting and erosion of the sedimentary sequence resulted in a general outcrop pattern consisting of Late Jurassic deposits to the west, Cretaceous sediments in the centre of the basin, and the youngest strata along the coast.

In the Tendaguru area, the Late Jurassic to Early Cretaceous Tendaguru Beds are well exposed in several small streams in the vicinity of Tendaguru Hill, especially at Tingutinguti, Dwanika and Maimbwi (Fig. 1). The Lower Saurian Bed is largely buried under deposits of the Mbwemkuru floodplain, and only the basal part of the Trigonia schwarzi Bed can be seen, exposed at the top of Tendaguru Hill.

\section{Methods}

This study focuses on our own bed-by-bed compilation of palaeontological and geological data for the Tendaguru area (Fig. 2). Stratigraphically less constrained information from previous expeditions was included where appropriate. In particular, this concerns the dinosaur assemblage, since renewed excavations of large vertebrates were not part of the current project. The topographic location of the dinosaur-bearing sites of the GTE were described by Janensch (1914a, 1925a) and Heinrich (1999a). Several sections of the Tendaguru Beds were measured sedimentologically, and 187 sediment samples were taken back to the laboratory. Their bulk composition was estimated by X-ray diffraction (XRD) analyses of non-oriented powder samples. Clay mineral analyses were carried out on textured mounts from selected samples. Data on the chemical composition were obtained from X-ray fluorescence. The microfacies of sediments was investigated by optical microscopy of thin sections.

Quantitative biostratinomic data for macroinvertebrates were collected in the field. Fossiliferous bulk samples were taken from single layers of uniform lithology. These were mechanically disaggregated to obtain the macroinvertebrate fauna, which, where possible, was then analysed using statistical techniques. To recover microfossils (microvertebrates, juveniles of molluscs, ostracods, foraminifera, charophytes), the samples were first treated with warm water and/or $\mathrm{H}_{2} \mathrm{O}_{2}$. Microvertebrate samples were also treated with acetic acid (about $5 \%$ by volume). The residues obtained were washed with water through a mesh, dried and hand-sorted using a binocular microscope.

The intensive weathering of surface material often hampers palynological investigations in tropical areas. Therefore every effort was undertaken to obtain fresh samples. Laboratory processing of samples involved the usual $\mathrm{HCl} / \mathrm{HF}$ extraction and $15 \mu \mathrm{m}$ sieving, but oxidation of the acid-resistant residues was avoided.
Cuticles were prepared according to standard procedures. Fossil plant-bearing rocks were bulk-macerated in $45 \%$ hydrofluoric acid, washed with distilled water, macerated using Schulze's reagent $\left(\mathrm{HNO}_{3}\right.$ and $\left.\mathrm{KClO}_{3}\right)$ and rinsed with $\mathrm{KOH}$. After gentle dehydration in pure glycerine, cuticles were mounted on slides using glycerine-jelly. Fusain was mechanically prepared using steel needles or obtained by sieving after disaggregation of samples with water or $\mathrm{H}_{2} \mathrm{O}_{2}$. Subsequently, the fusain was mounted on SEM stubs, coated with gold-palladium and examined using a Jeol JMS 6300 electron-microscope.

The fossil material figured in Plates $1-2$ is housed at the Museum für Naturkunde, Humboldt Universität Berlin (MB.) and the Institut für Angewandte Geowissenschaften, Technische Universität Berlin (IY).

\section{Stratigraphy}

In the type area, the Tendaguru Beds (Janensch 1914b) lie unconformably on Proterozoic basement rocks and reach a thickness of approximately $110 \mathrm{~m}$. Three fine-grained dinosaur-bearing sequences (Lower, Middle and Upper Saurian Beds), each $10-30 \mathrm{~m}$ thick, are intercalated with sandstone-dominated sequences containing a predominantly marine fauna and reaching thicknesses of up to $30 \mathrm{~m}$ (Nerinea Bed, Trigonia smeei Bed, Trigonia schwarzi Bed) (Fig. 2). These six main stratigraphic intervals probably correspond to the modern stratigraphic equivalent of members, but are not formally defined here, pending further studies. The term Tendaguru Formation has been proposed by Schudack (1999), but has not yet been formally defined or described. Towards the east, the thickness of the sandstone-dominated sequences increases, whereas those of the Saurian beds decreases (Hennig 1937). Laterally, the siliciclastic sediments of the Trigonia smeei Bed interfinger with carbonates. The sandstones of the Tendaguru Beds are rich in feldspars and the matrix consists mainly of calcite. The clay mineral fractions are dominated by smectite and illite. By contrast to the sandstones of the Nerinea and the Trigonia smeei Bed, the sandstones of the Trigonia schwarzi Bed have higher potassium feldspar/plagioclase feldspar-ratios. Altogether, ten lithofacies types were identified. They are summarized in Table 1 and discussed below.

The biostratigraphy of the Tendaguru Beds has been much debated, but a Late Jurassic to Early

Fig. 2. Composite section of the Tendaguru Beds in the type area with stratigraphic position of samples and distribution of major fossil groups within the section. For geographical location of samples and their abbreviations see Fig. 1 . Based on new data of the German-Tanzanian Tendaguru Expedition 2000. 
Table 1

Lithofacies types for the Tendaguru Beds and their interpretation

\begin{tabular}{|c|c|c|c|}
\hline lithofacies & lithology & sedimentary structures & interpretation \\
\hline 1 & sandstone, with solitary bioclasts & trough cross-bedding & tidal channel fills \\
\hline 2 & sandstone, bioclast-rich & $\begin{array}{l}\text { massive or crude cross-bedding, } \\
\text { bioturbations, }\end{array}$ & final fill of tidal channels \\
\hline 3 & sandstone, well sorted & trough or tabular cross-bedding & tidal bars \\
\hline 4 & sandstone, well sorted & $\begin{array}{l}\text { low angle cross-bedding to } \\
\text { horizontal bedding }\end{array}$ & beach deposits \\
\hline 5 & $\begin{array}{l}\text { sandstone, coarse-grained; } \\
\text { conglomerate, poorly sorted }\end{array}$ & megaripples, shell beds & tempestites \\
\hline 6 & sandstone, fine-grained; siltstone & $\begin{array}{l}\text { ripple cross-bedding to } \\
\text { laminated, flaser and lenticular } \\
\text { bedding }\end{array}$ & tidal flat deposits \\
\hline 7 & micritic carbonate & peloidal, cracks & calcretes \\
\hline 8 & $\begin{array}{l}\text { sandstone, fine-grained; } \\
\text { minor silt- and claystone }\end{array}$ & $\begin{array}{l}\text { ripple cross-bedding, horizontal } \\
\text { bedding, massive }\end{array}$ & $\begin{array}{l}\text { fluvial channel fills, floodplain } \\
\text { and lake deposits }\end{array}$ \\
\hline 9 & calcareous oolite & $\begin{array}{l}\text { cross-bedding, massive, or } \\
\text { bioturbated }\end{array}$ & ooid bars \\
\hline 10 & limestone & in situ corals and molluses & coral-oyster biostromes \\
\hline
\end{tabular}

Cretaceous age is generally accepted. Biostratigraphy of the marine units depends heavily on ammonites and bivalves, but age assignments are not consistent (see Aitken 1961). Preliminary biostratigraphic interpretations of our samples support the following dates: Oxfordian? to Late Kimmeridgian for the Nerinea Bed (based on the ostracod Majungaella oxfordiana, Bate (1975) and ammonites (G. Schweigert, pers. comm., 2002 and Heinrich et al. 2001)); early Tithonian for the Trigonia smeei Bed (based on ammonites (G. Schweigert, pers. comm., 2001) and charophytes (M. Schudack, pers. comm., 2002)); and Early Cretaceous, possibly Valanginian to Hauterivian, for the Trigonia schwarzi Bed (based on palynomorphs (Heinrich et al. 2001)).

\section{Sedimentological and palaeontological analysis}

\section{Lower Saurian Bed}

\section{Facies}

The Lower Saurian Bed consists predominantly of ripple cross-bedded, fine-grained sandstones and siltstones interbedded with massive clay-rich siltstones.

Invertebrates

Macrobenthic molluscs are remarkably rare (samples Tin 1, Tin 0a), but mesobenthic $(<5 \mathrm{~mm})$ elements are abundant in more than twenty samples from horizon Tin $0 \mathrm{a}$. They constitute a moderately diverse assemblage domi- nated by juveniles of the bivalves Meleagrinella radiata (Pl. 2: 5), Liostrea dubiensis, Nanogyra nana and Eomiodon cutleri, as well as the gastropods Pseudomelania dietrichi, Cryptaulax sp. and Promathildia sp.. Rare elements include serpulid worm tubes, crustaceans (two species of ostracods, including Pirileberis; decapod crab), benthic foraminifera and fragments of echinoids and crinoids. Of the highly inequivalved $M$. radiata, right valves were twice as common as left valves. Both taxonomic composition and relative abundance hardly vary between samples, and $6.7 \%$ of the bivalves were still articulated.

\section{Vertebrates}

Comparatively few vertebrate remains are known from the Lower Saurian Bed, and all are disarticulated. Sample Tin 0a yielded a single vertebra of an indeterminate teleost fish as well as poorly preserved scales and bones of fishes that do not permit taxonomic determination (Arratia et al. 2002). Other aquatic or semi-aquatic vertebrates have not yet been recovered. The only terrestrial vertebrates known to date were reported by the GTE (Janensch 1961, see Table 2). The material includes the distal end of a large femur and a small manus claw of the sauropod Brachiosaurus brancai. The femur represents an adult, the small claw is apparently from a juvenile individual. Several isolated teeth assigned to the theropod 'Megalosaurus ingens' and some theropod teeth that might belong to 'Ceratosaurus roechlingi' and 'Allosaurus tendagurensis' were also found (Janensch 1925b). 


\section{Flora}

A few samples from the Lower Saurian Bed (Tin 1, Tin 0a) yielded an impoverished palynoflora. The dominant element are pollen grains of the conifer family Cheirolepidiaceae (Classopollis) associated with pollen from other conifers (bisaccate pollen, Araucariacites), possible representatives of the Podocarpaceae and Araucariaceae, and a few pteridopyhtic spores. No marine palynofossils were observed.

Similarly, the mesoflora is dominated by cuticles of cheirolepidiaceans (Tin 0b; Pl. 1: 6), while cuticles of the Araucariaceae and ginkgos are less common.

\section{Environmental interpretation}

The sediments of the Lower Saurian Bed suggest variable water energies of low to moderately high intensity. The marked asymmetry in valve sorting of shells points to selective transport by currents and/or waves. However, the unvariable faunal composition and frequency distributions of samples and the occurrence of articulated shells render large-scale transport and faunal mixing unlikely. Consistent with the general setting of the Tendaguru Beds (see below), the sediments and invertebrate assemblages of the Lower Saurian Bed are tentatively assigned to a tidal flat environment. The invertebrate fauna clearly demonstrates a marine influence. However, the dominance of generally eurytopic bivalves and gastropods, relatively low diversities and the extreme abundance of juvenile invertebrates suggest a certain degree of environmental stress. This may have its origin in a combination of salinity fluctuations and relatively long subaerial exposure times that shorten the time available for suspension-feeding.

With respect to the few vertebrate remains, adult brachiosaurs are generally regarded as high-browsing herbivores (e.g., Paul 1988, McIntosh 1997), whereas small juvenile and mediumsized subadult individuals of Brachiosaurus brancai must have fed closer to the ground. Like other sauropods, B. brancai was essentially terrestrial (McIntosh 1997). The admittedly poor fossil record of terrestrial vertebrates suggests a vegetated environment in the hinterland of Tendaguru with habitats where juvenile and adult brachiosaurs could gather food from high- and low-growing plants, of which so far conifers, ginkgos and pteridophytes can be demonstrated. The region was also inhabited by large predators/scavangers such as Megalosaurus ingens. The existence of water bodies is indicated by fish remains. It is possible that the terrestrial vertebrate assemblage achieved similar levels of diversity as that from the Middle and Upper Saurian Beds, but this idea cannot be tested because of the small size of the sample, and possible collection bias.

\section{Nerinea Bed}

\section{Facies}

The base of the Nerinea Bed consists of trough cross-bedded or massive, poorly sorted, mediumto coarse-grained sandstones. The sandstones form fining-upward sequences and show highly variable to bipolar transport directions. They are occasionally overlain by massive to indistinctly cross-bedded fine- to medium-grained sandstones that sometimes contain a diverse assemblage of invertebrates. Stacked sequences of mainly trough cross-bedded, medium- to fine-grained sandstones with unimodal transport directions are also common. Further lithofacies types comprise well sorted, horizontally to low-angle crossbedded sandstones and isolated swaley crossbedded sandstones (Pl. 1: 1).

\section{Invertebrates}

The bivalve taxa from the Lower Saurian Bed also occur scattered through several sandstone layers at the base of the Nerinea Bed (e.g., Tin 2, Tin $3 /$ base, Tin $3 b$ ), where they reach maximum sizes that are distinctly larger. Additional common elements are the bivalves Protocardia schencki, Grammatodon irritans and various species of limids and pectinids, whereas gastropods are rare. Also rare are nektic elements including ammonoids, nautiloids and belemnites. The calcareous microfauna in these samples is represented by a moderately diverse ostracode assemblage, including Majungaella oxfordiana ( $\mathrm{Pl} .2$ : 8) and Cytherella umbilica (Pl. 2: 12) and benthic foraminifera. The most fossiliferous sample (Tin 3d) stems from calcareous concretions within a bioturbated, fine-grained sandstone. It is dominated by epifaunal and infaunal, suspension-feeding bivalves that are fairly evenly distributed in terms of their relative abundances (Fig. 3). The left/right valve ratio of the most common taxa is close to one and double-valved individuals occur. The levels of fragmentation, abrasion, encrustation and bioerosion are low. This layer also yielded six species of ostracods, including Cytherella 

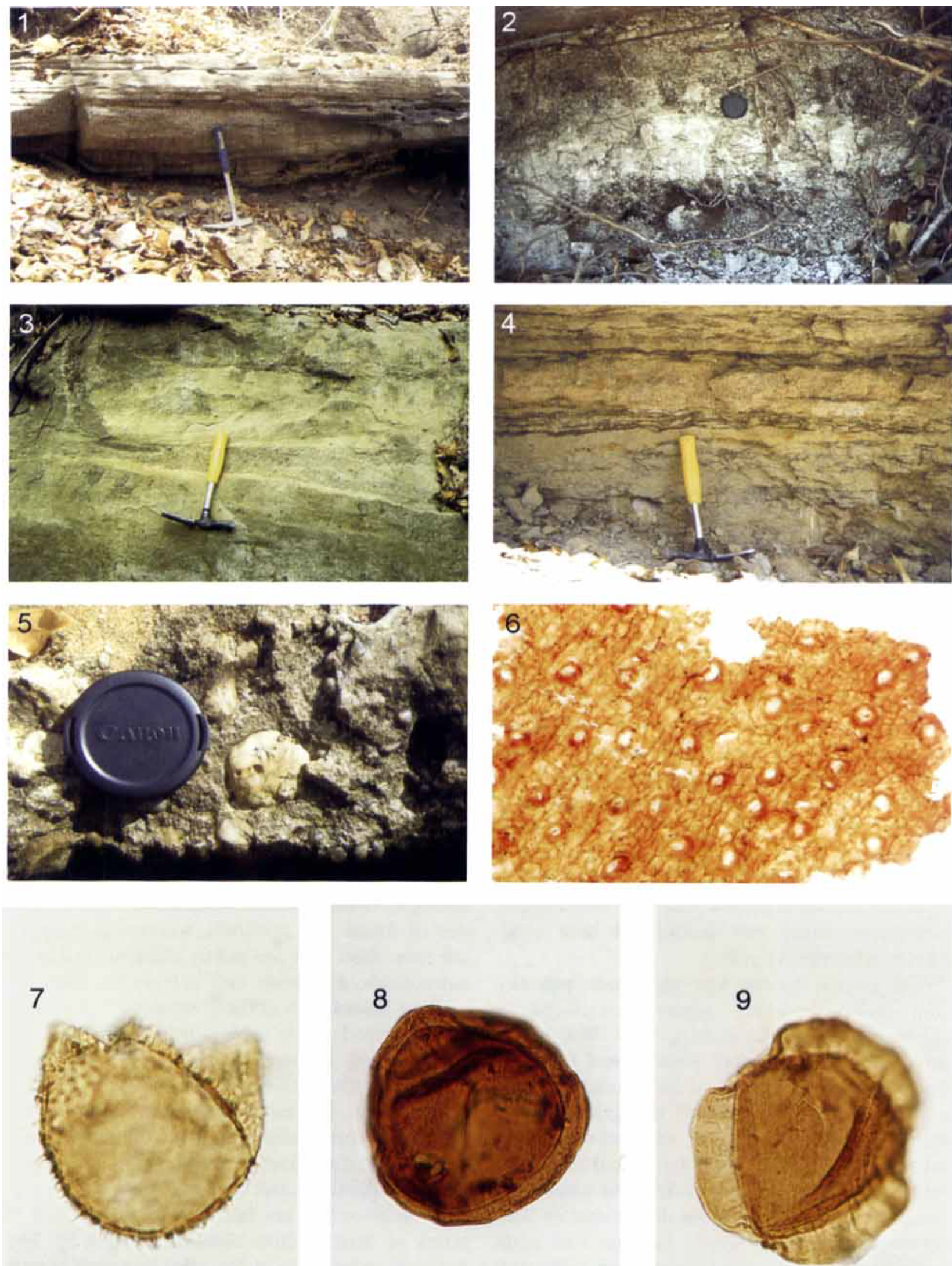


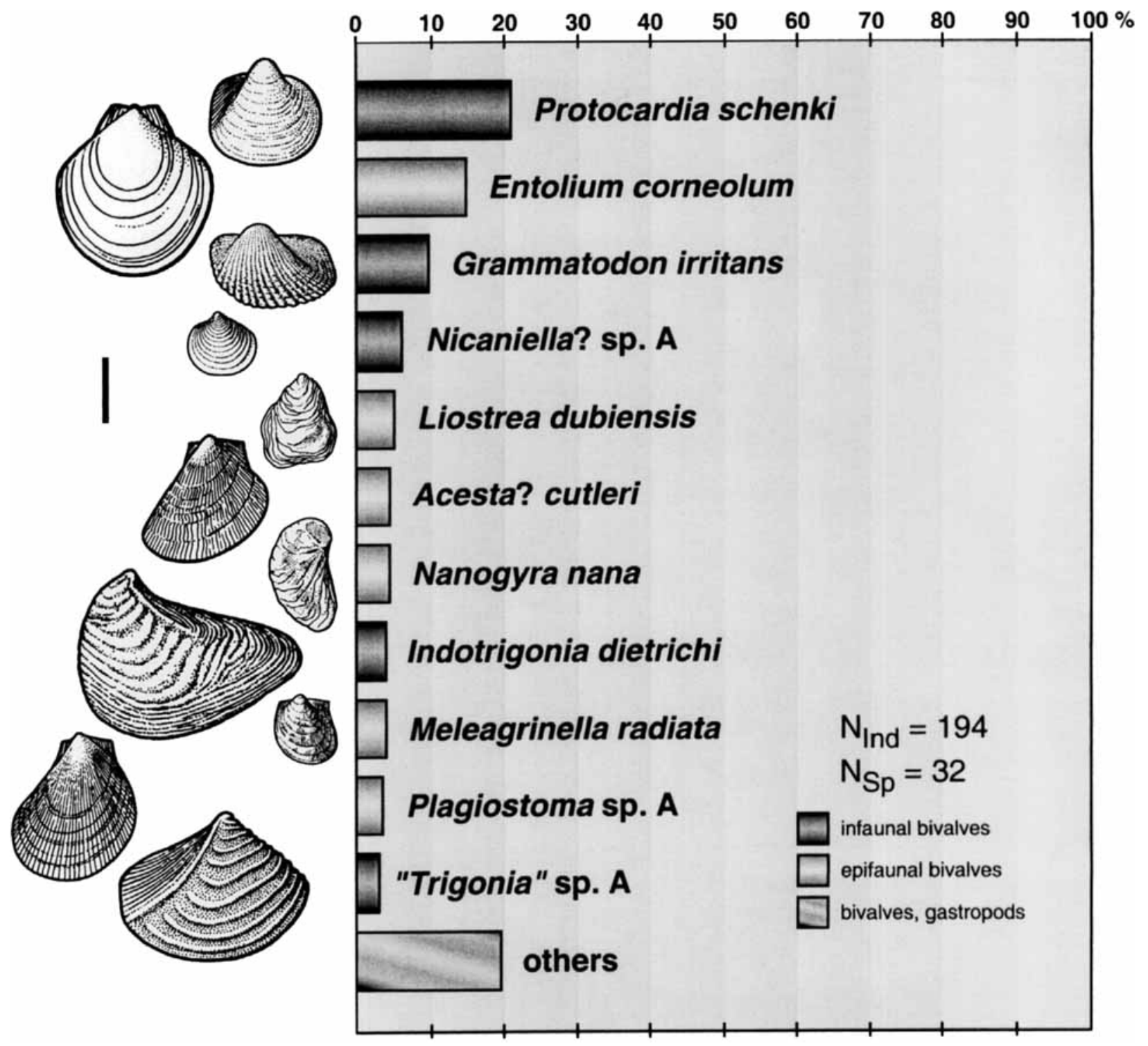

Fig. 3. Faunal composition and relative abundance of macroinvertebrates in sample Tin $3 \mathrm{~d}$. Scale bar equals $1 \mathrm{~cm}$. $\mathrm{N}_{\text {Ind }}$ number of individuals; $\mathrm{N}_{\mathrm{Sp}}$ : number of species.

sp. and Majungaella $\mathrm{cf}$ oxfordiana, as well as benthic foraminifera.

\section{Vertebrates}

According to Janensch (1914b) and (Hennig 1914a), the marine sandstone units separating the three dinosaur-bearing units yielded only insignificant fragments of dinosaur bones. Wellpreserved vertebrate remains from the Nerinea Bed are still to be discovered.
Flora

Palynofloras are again dominated by conifer pollen (mainly Classopollis, but also Araucariacites). Low diversity or monospecific assemblages of dinoflagellates occur in samples Tin 2 and Tin $4 d$ and somewhat more diversified assemblages with Barbatacysta, Gonyaulacysta group and chorate cysts were found in samples Tin $3 b$ and Tin $3 d$. Sample Tin $4 \mathrm{~d}$ yielded psilate ?dinoflagellates.

Colour-Plate 1. 1. Low-angle cross-bedded beach sandstones in the Nerinea Bed; Tingutinguti stream section. 2. Calcrete horizon in the Middle Saurian Bed; Tingutinguti stream section. 3. Trough cross-bedded tidal channel sandstones in the Trigonia smeei Bed; Dwanika stream section. 4. Heterogenous intertidal sediments in the Trigonia smeei Bed; Tingutinguti stream section. 5. Conglomerate horizon in the Trigonia smeei Bed; small tributary of the Bolachikombe stream. 6. Cheirolepidiocutis sp. (cuticule of a cheirolepidiacean conifer); Lower Saurian Bed, sample Tin 0b, $\times 57$; MB.Pb.2002/1045. 7. Barbatacysta creberbarbata (Erkmen \& Sarjeant) Courtinat (marine dinoflagellate); Trigonia smeei Bed, size $36 \mu \mathrm{m}$; IY27. 8. Densoisporites velatus Weyland \& Krieger (pteridophytic spore); Middle Saurian Bed, size $52 \mu \mathrm{m}$; IY15. 9. Callialasporites trilobatus (Baime) Sukh Dev (conifer pollen with affinity to Araucariaceae); Middle Saurian Bed, size $60 \mu \mathrm{m}$; IY31. 


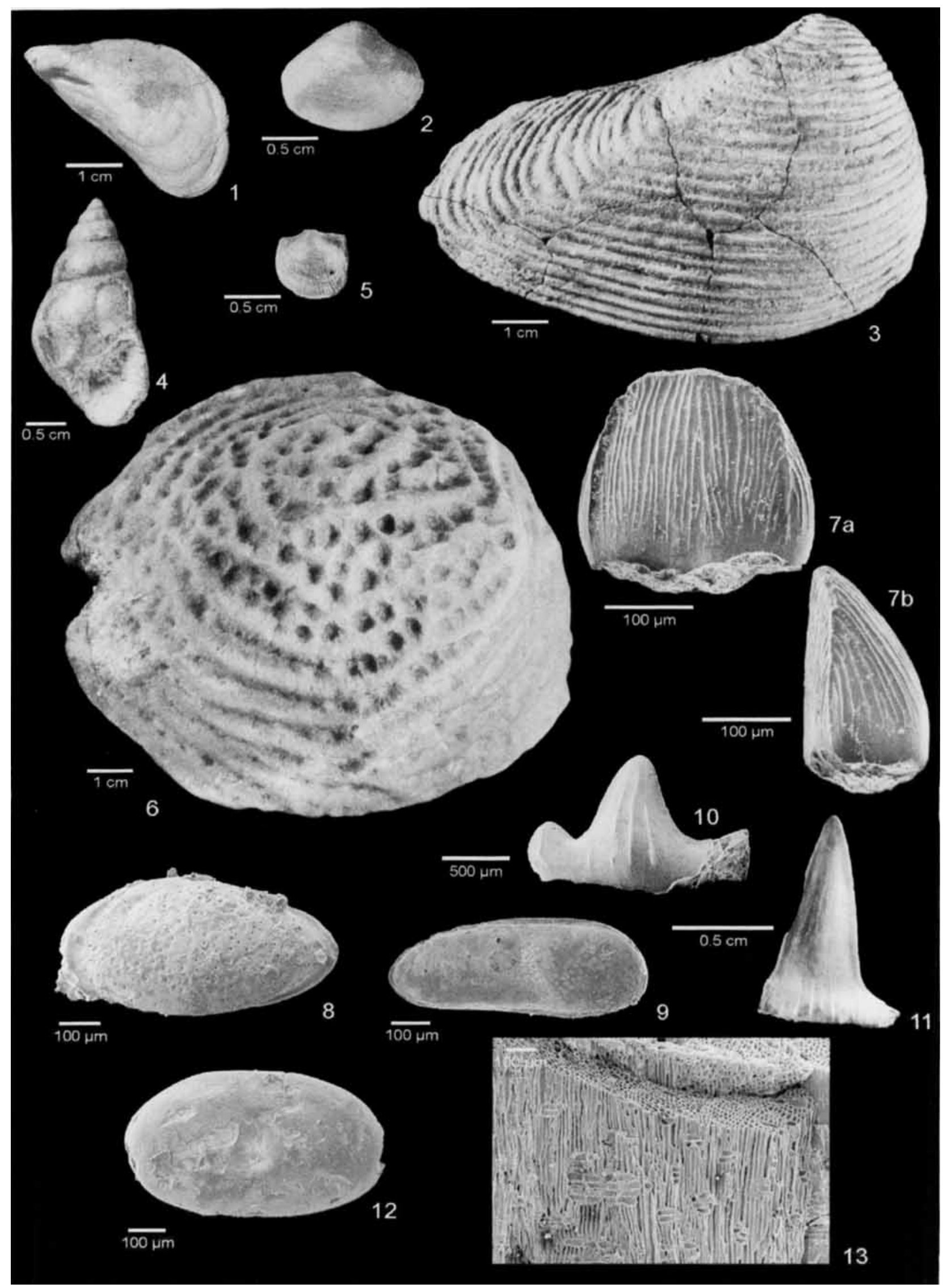


The mesoflora is rather rare but seems to be diverse. In sample Tin $3 \mathrm{~d}$ Cheirolepidiaceae, Podocarpaceae, Ginkgoales and Cycadales are found as cuticules. A new conifer genus is preserved as fusain.

\section{Environmental interpretation}

Trough cross-bedded sandstones with evidence of bipolar and variable transport directions were most likely deposited in tidal channels. The highly fossiliferous invertebrate sample from bioturbated sandstone (Tin 3d) probably represents the final fill of such a tidal channel. In this sample, the balanced proportion of epifauna to infauna suggests a stable, but still relatively soft substrate. The taphonomic data indicate that post-mortem transport was insignificant and that the residence time of shells on the sediment surface was short. Faunal composition, the maximum size of taxa and diversity values testify to normal marine conditions. The moderately diverse assemblages of dinoflagellates, ostracods and benthic foraminifers in the same sample support this view. It must be kept in mind, however, that this sample is not representative for the Nerinea Bed as a whole. In particular, higher parts of this unit are unfossiliferous or poorly fossiliferous with relatively low diversity. Sample Tin $4 \mathrm{~d}$, for example, only yielded questionable psilate dinoflagellates suggesting some form of environmental stress, possibly fluctuating salinities. The absence or scarcity of skeletal hardparts is not necessarily the result of a primary absence of shellbearing invertebrates, but may be due to shell dissolution during early diagenesis. Nothing is known so far about the marine vertebrate fauna of the Nerinea Bed and its coeval terrestrial counterparts.

Sandstones with unimodal transport directions are interpreted as subtidal sand bars. Horizontally to low-angle cross-bedded sandstones are most likely to represent beach deposits (Pl. 1: 1), whereas swaley cross-bedded sandstones probably formed as storm layers (tempestites). Over- all, the Nerinea Bed appears to represent very shallow subtidal to lower intertidal environments that were strongly influenced by tides and, at least intermittently, by storms.

\section{Middle Saurian Bed}

\section{Facies}

The basal part of the Middle Saurian Bed is composed of fining-upward sequences that consist of ripple cross-bedded, fine-grained sandstones and siltstones, and massive silt- and claystones. These sediments are cut by lenses consisting of ripple cross-bedded sandstones. In the upper part, several peloidal limestone horizons are intercalated within the main sequence (Pl. 1: 2). Limestone intraclasts are also present in adjacent sandstone beds.

\section{Invertebrates}

Several samples from the base of the Middle Saurian Bed (Tin 6, Tin 7b) yielded a macrobenthic mollusc assemblage characterised by low species richness and high dominance. Representing nearly $80 \%$ of the total number of specimens, the shallow burrowing neomiodontid bivalve Eomiodon cutleri (= Cyrena sp. of Dietrich 1933; e.g., Pl. 2: 2) strongly dominates. Individuals of this species exhibit a broad size spectrum, high degree of articulation and low degree of fragmentation. Two species of gastropds, Promathildia sp. and Pseudomelania dietrichi (PI. 2: 4), and a mytilid bivalve are far less common (Fig.4). Stenohaline groups such as corals and echinoderms appear to be absent. The mesobenthos is dominated by juveniles of Promathildia. Ostracods are common, moderately diverse and include the genus Darwinula (Pl. 2: 9).

In the remainder of the Middle Saurian Bed macro- and microinvertebrates only occur sporadically. Rare ostracods from samples Tin $7 d$ and

Plate 2. 1. Falcimytilus dietrichi Cox (bivalve), left valve view; Upper Saurian Bed, GTE site I; MB.M.1566. 2. Eomiodon (Africomiodon) cutleri Cox (bivalve), right valve view; Upper Saurian Bed, GTE site G; MB.M.1645.1. 3. Indotrigonia ex gr. smeei (J. de C. Sowerby) (bivalve), right valve view; Trigonia smeei Bed, sample Mai 5/Bed 1; MB.M.1708. 4. Pseudomelania dietrichi Cox (gastropod); Middle Saurian Bed, GTE site p; MB.Ga.1120.1. 5. Meleagrinella radiata (Trautschold) (bivalve), left valve view; Nerinea Bed, sample Tin 3d; MB.M.1711.1. 6. Meandrophyllia oolitotithonica (Dietrich) (coral); Trigonia smeei Bed, sample Kor 24; MB.K.1594. 7. Bernissartia sp. (tooth of a dwarf crocodile); Middle Saurian Bed (bone bed Wj), GTE site dy; MB.R.3259; a, lingual view; b, ?anterior view. 8. Majungaella oxfordiana Bate (ostracod); external view of male left valve; Nerinea Bed, sample Tin 2a. 9. Darwinula sp. (ostracod); internal view of right valve; Middle Saurian Bed, sample Tin 7b. 10. Hybodus sp. (tooth of selachian fish); labial view; Upper Saurian Bed, sample Dwa 5a; MB.f.7732. 11. Sphenodus sp. (tooth of a selachian fish); labial view; Upper Saurian Bed, GTE site Om; MB.f.7729. 12. Cytherella cf. umbilica Bate (ostracod); external view of right valve; Nerinea Bed, sample Tin 2a. 13. Glyptostroboxylon n. sp. (conifer); Trigonia smeei Bed, sample Tin 9h; MB.Pb.2002/1044; scale bar equals $100 \mu \mathrm{m}$. 
Tin $7 \mathrm{~g}$ contain Cypridea sp., and sample Tin $7 \mathrm{i}$ yielded Darwinula sp. Bivalves and gastropods (samples Tin 7c, f, i, k, l) include the above-mentioned taxa as well as small individuals of the eurytopic oysters Liostrea and Nanogyra.

\section{Vertebrates}

The Middle Saurian Bed, as exposed in the Tingutinguti stream section, produced only a few, small fragments of bones and teeth of dinosaurs that do not show any diagnostic features, and fish remains (Heinrich et al. 2001). Teeth of a selachian, scales and teeth of Lepidotes sp., as well as a scale of a pholidophorid-like fish and vertebrae of an indeterminate teleost have been identified (Arratia et al. 2002). A selachian spine collected from the Middle Saurian Bed exposed at site Bo was previously reported by Hennig (1914b).

The dinosaurs recovered by the GTE are the hallmark of the Middle Saurian Bed (Table 2). The following sauropods have been identified:

\section{Table 2}

Stratigraphic distribution of vertebrate taxa of the Tendaguru Beds. Note that the Transitional Beds of previous workers are here included in the corresponding Saurian beds. The sandstone units separating the three dinosaur-bearing units yielded no or only insignificant fragments of vertebrate remains, which are referred to in the text. $(+)$ denotes that stratigraphic position is uncertain;? denotes that taxonomic assignment is uncertain.

\begin{tabular}{llll}
\hline Taxa & Lower & Middle & Upper \\
& Saurian Bed & Saurian Bed & Saurian Bed
\end{tabular}

\section{Elasmobranchii}

Hybodus sp.

Hybodontidae indet

Lonchidion sp. nov.

Sphenodus sp.

Indet. Selachian

Engaibatis schultzei Arratia et al., 2002

Actinopterygii

Lepidotes tendaguruensis Arratia \& Schultze, 1999

Lepidotes $\mathrm{sp}$.

'Pholidophorid'

Inder. teleost

Indet. fishes

Amphibia

Lissamphibia (Salientia?).

\section{Reptilia}

Sphenodontidae indet.

Paramacellodidae indet.

Bernissartia sp.

Crocodylia indet.

Tendaguripterus recki Unwin \& Heinrich, 1999

Dsungaripteroidea indet.

'Rhamphorhynchoidea' indet.

Elaphrosaurus bambergi Janensch, 1920

Coelurosauria indet.

'Allosaurus tendagurensis' Janensch, 1925

'Ceratosaurus roechlingi' Janensch, 1925

'Labrosaurus stechowi' Janensch, 1920

'Megalosaurus ingens' Janensch, 1920

Theropoda indet.

Barosaurus africanus (Fraas, 1908)

Barosaurus gracilis Janensch, 1961

Dicraeosaurus hansemanni Janensch, 1914c

Dicraeosaurus sattleri Janensch, 1914c

Brachiosaurus brancai Janensch, 1914c

Janenschia robusta (Fraas, 1908)

Tendaguria tanzaniensis Bonaparte et al., 2000$$
\text { Saurian Bed }
$$

Sauropoda indet.

Kentrosaurus aethiopicus Hennig, 1915

Dryosaurus lettowvorbecki (Virchow, 1919)

Dinosauria indet.

Mammalia

Staffia aenigmatica Heinrich, 1999

Tendagurodon janenschi Heinrich, 1998

Brancatherulum tendagurense Dietrich, 1927

Tendagurutherium dietrichi Heinrich, 1998

Mammalia indet.

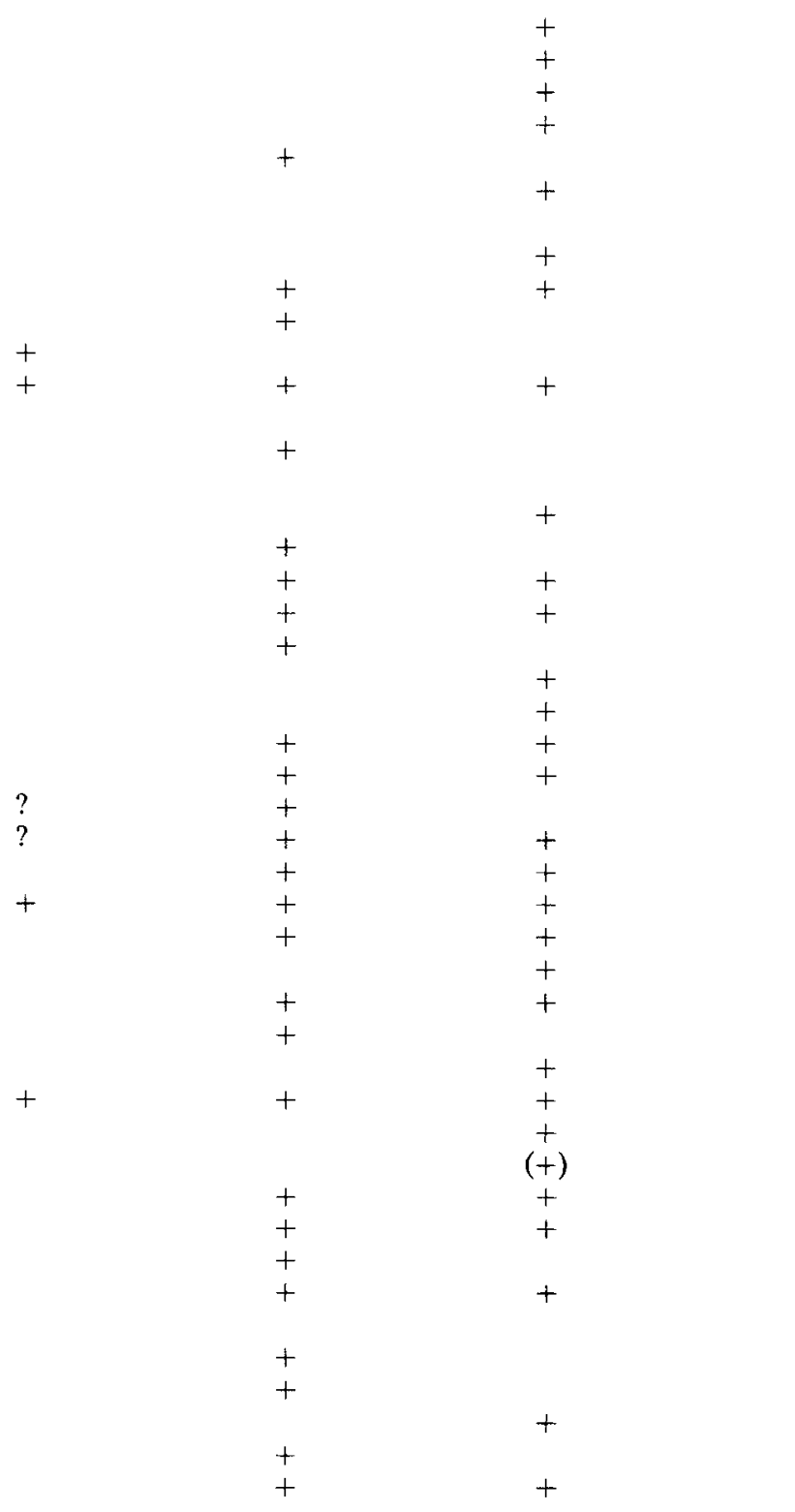


Brachiosaurus brancai, Dicraeosaurus hanseman$n i$ and Barosaurus gracilis (Janensch 1914c, 1961). They are associated with theropods, among them Elaphrosaurus bambergi, 'Megalosaurus ingens', 'Labrosaurus stechowi' and 'Allosaurus tendagurensis' (Janensch 1925b). In addition, two ornithischians are reported (Hennig 1925, Janensch 1955), Kentrosaurus aethiopicus and Dryosaurus lettowvorbecki.

The transitional sands between the Middle Saurian Bed and the Trigonia smeei Bed, here included in the Middle Saurian Bed, contain skeletal remains of Barosaurus gracilis, Dicraeosaurus sp., Brachiosaurus brancai and Kentrosaurus aethiopicus (Hennig 1925, Janensch 1961). These assemblages are dominated by disarticulated limb bones, many of which are water-worn. Site Aa produced a fragmentary humerus of $B$. brancai overgrown by oysters (Janensch, GTE field book, p. 140). Site p, immediately overlying the Nerinea Bed, yielded a string of nearly articulated caudal vertebrae of the same species that were associated with marine invertebrates including the bivalve Eomiodon, gastropods and stalk fragments of crinoid stems (Hennig 1914a; Janensch, GTE field book, p. 56).

Based on field sketches of the GTE, Heinrich (1999a) distinguished four main preservational states of dinosaurs from the Middle Saurian Bed: (1) fairly complete skeletons (e.g., Brachiosaurus brancai, site S; Dicraeosaurus hansemanni, site m); (2) partial skeletons (e.g., Dryosaurus lettowvorbecki, site dy); (3) bone fields consisting mainly of disarticulated bones (e.g., Kentrosaurus aethiopicus, site $\mathrm{St}$ ); and (4) solitary bones and teeth (most taxa and sites). Multi-taxon assemblages (e.g., site Q: B. brancai, D. hansemanni, $K$. aethiopicus) and single-taxon bone assemblages (e.g., site S: B. brancai, site m: D. hansemanni) have been recognized. In the latter category, single-individual assemblages (e.g., $D$. hansemanni, site $\mathrm{m}$ ) and multi-individual assemblages (e.g., B. brancai, sites S, XX) can be distinguished. The bone assemblages of $B$. brancai are dominated by adult and old adult individuals (Heinrich 1999a). By contrast to the sauropods and ornithischians, the theropod dinosaurs are mainly represented by isolated teeth and bones, except for the incomplete skeleton of Elaphrosaurus bambergi recovered from site dd (Janensch 1925b).

Acid preparation of matrix recovered from two bone beds $(\mathrm{Jg}, \mathrm{Wj})$ at site dy by the GTE yielded skeletal remains of small, land-dwelling vertebrates including lissamphibians (Salientia?), sphenodontid lepidosaurs, squamates (Paramacellodidae indet.: Broschinski 1999) and crocodiles (e.g., Bernissartia: Heinrich et al. 2001; see also Janensch 1914b; Pl. 2: 7). Pterosaurs (Tendaguripterus recki: Unwin \& Heinrich 1999) and mammals have also been recovered, the latter represented by a jaw fragment of an eupantothere (Tendagurutherium dietrichi), a tooth of a triconodont (Tendagurodon janenschi) and cheek teeth of a haramiyid (Staffia aenigmatica) (Heinrich 1998, 1999b, 2001; Table 2).

\section{Flora}

Again, pollen grains derived from a conifer-dominated terrestrial vegetation are the most abundant palynomorphs in the Middle Saurian Bed (e.g., Pl. 1: 9). Dinoflagellates are rare and include short-spined forms (Tin 6) and psilate forms (Tin 7b). Freshwater algae (Zygnemataceae: Ovoidites, see Schrank 1999) occur in Tin 6 and Tin $7 \mathrm{f}$. In sample Tin $7 \mathrm{~d}$ two specimens of fairly well-preserved charophytes were found.

With respect to cuticles, Tin $7 \mathrm{f}$ constitutes the most productive sample within the Tendaguru Beds, yielding a nearly monotypic assemblage of Cheirolepidiaceae and a few specimens representing Podocarpaceae.

\section{Environmental interpretation}

The majority of fine-grained sediments from the basal part of the Middle Saurian Bed were deposited on siliciclastic tidal flats of a lagoonal system, whereas the sandstone lenses represent small tidal channels. The taphonomic data from macrobenthic assemblages in this part of the section indicate the absence of large-scale lateral transport and sorting of valves by currents. By analogy with modern ecosystems, low diversity, high abundance and large populations hint at an elevated degree of environmental stress. Eomiodon has long been recognised as an eurytopic bivalve, capable of tolerating reduced salinities (e.g., Huckriede 1967, Hallam 1976, Fürsich 1994). This, in combination with the lack of stenohaline groups and the marginal marine setting of the Tendaguru Beds, is indicative of low-energy, brackish water environments, an interpretation that is supported by the presence of the ostracod Darwinula and of rare short-spined and psilate dinoflagellates in the same samples. Both the dinoflagellates (e.g., Schrank \& Mahmoud 1998) and the ostracod (van Morkhoven 1963, Neale 1988) provide evidence for the influence of fresh to slightly oligohaline waters. The abundance of juveniles of Promathildia sp. suggests 
that this species lived close to the limits of its environmental tolerance. Periodically, fluctuating salinity values probably caused high juvenile mortality. According to Dietrich (1933) shell beds dominated by Cyrena sp. (= Eomiodon) and indicative of weakly brackish water conditions occur repeatedly in the Jurassic part of the Tendaguru Beds.

The presence of the nonmarine ostracod genus Cypridea (see Neale 1988) together with wellpreserved charophytes and other freshwater algae, indicates the strong influence of freshwater in Tin 6, Tin 7d, Tin $7 \mathrm{f}$ and Tin $7 \mathrm{~g}$. Ostracods from the Middle Saurian Bed and of partly marine and partly freshwater affinities, as well as charophytes suggesting environments with partly brackish, partly freshwater influences were also reported by Schudack (1999) and Schudack \& Schudack (2002).

Peloidal limestones in the upper part of the Middle Saurian Bed are interpreted as pedogenic calcretes (Pl. 1: 2). Their presence indicates periods of subaerial exposure and the onset of soil formation. Calcrete intraclasts within adjacent sandstone beds testify to erosive reworking of calcrete horizons. The highly sporadic occurrence, in this part of the section, of molluscs typical of marginal marine habitats indicates only a very weak marine influence. We interpret the corresponding environments as sabkha-like coastal plains with brackish lakes and ponds.

With regard to the land-dwelling vertebrate assemblage a crucial issue is the degree to which post-mortem transportation of dinosaur remains may have taken place. The broad spectrum of disarticulation stages and the water-worn nature of many bones indicate carcass decay and a certain amount of post-mortem transport prior to burial (Heinrich 1999a). Mass accumulations of mainly disarticulated bones of the herbivorous dinosaurs Kentrosaurus aethiopicus (site St) and Dryosaurus lettowvorbecki (site dy) were originally thought to represent a sudden mass death event due to drowning (Janensch 1914a, c; Hennig 1925). More recently, Russell et al. (1980: 172) speculated that these mass accumulations "may be interpreted as the result of a concentration of low-browsing herbivores in a restricted area of relatively plentiful, low-growing vegetation during a period of drought. Overpopulation led to overexploitation and an abundance of skeletal litter which was swept into concentrations by flowing water after the return of normal pluviosity". Our observations suggest that the dou- ble-peaked size distribution pattern for the femur of D. lettowvorbecki collected at site dy resulted from a year-to-year input of bones (Heinrich 1999a), rather than as a result of mass death events caused by a single period of drought. Subsequent reworking may have concentrated bones in lag deposits of tidal channels. The bone accumulations in the transitional sands below the Trigonia smeei Bed, dominated by abraded sauropod limb bones, are possibly due to wave and/or current action that resulted in the abrasion, destruction, transportation and sorting of skeletal elements (Janensch 1914b). The associated invertebrates show that marine waters influenced the depositional environment.

Among land-dwelling vertebrates the dominant group were large herbivorous dinosaurs. The largest species were quadrupedal sauropods, among them Brachiosaurus brancai which is generally assumed to have been able to reach up to $13 \mathrm{~m}$ to feed on tree foilage (e.g., Paul 1988, Christiansen 1995, McIntosh 1997, Christian \& Heinrich 1998). It was followed by the highbrowsing Barosaurus gracilis and the relatively short-necked Dicraeosaurus hansemanni, which probably fed at a lower level. By contrast, the foraging ranges of the low level-feeding ornithischians Kentrosaurus aethiopicus and Dryosaurus lettowvorbecki were possibly restricted to heights of no more than two meters above the ground. As at other dinosaur sites (Currie 1997), the flesh-eating theropods were outnumbered by herbivorous sauropods, even though the precise number of individuals, especially for the theropods, has still to be calculated. The pterosaur Tendaguripterus recki possibly fed on hardshelled invertebrates such as bivalves (D. Unwin, pers. comm., 2002), and is likely to have inhabited the coasts of a shallow sea and margins of rivers.

The taxonomic diversity of the herbivorous dinosaurs and their estimated foraging heights suggest a diverse vegetation in the hinterland, with numerous habitats and niches that also offered adequate living conditions for lissamphibians (Salientia?), terrestrial sphenodontid lepidosaurs, squamates and mammals. The triconodontid mammal Tendagurodon janenschi was most likely terrestrial and probably insectivorous or partly carnivorous, but the exact diet is unknown. The shrew-sized eupantothere Tendagurutherium dietrichi possessed shearing teeth (Heinrich 1998). It lived on land and possibly fed on insects and other small invertebrates. The haramiyid Staffia aenigmatica was a small terres- 


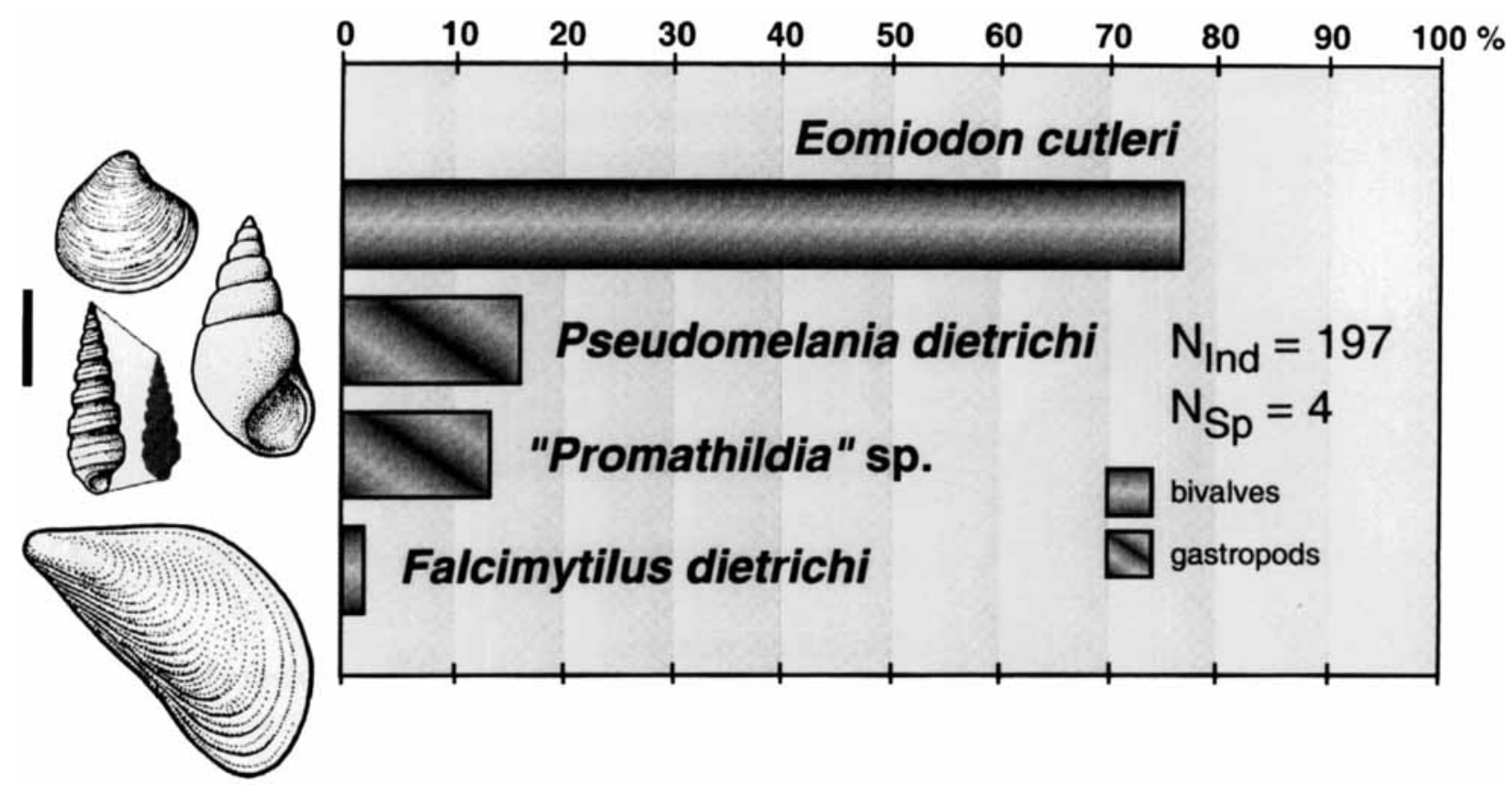

Fig. 4. Faunal composition and relative abundance of macroinvertebrates in sample Tin $7 \mathrm{~b}$. Scale bar equals $1 \mathrm{~cm}$. For key of abbreviations see Fig. 3.

trial allotherian mammal. Its dentition suggests that it processed soft food items such as plant material, as previously suggested for other haramiyid taxa (Butler \& McIntyre 1994). The presence of crocodiles indicates freshwater to littoral environments and adjacent terrestrial areas.

\section{Trigonia smeei Bed}

\section{Facies}

The Trigonia smeei Bed, like the Nerinea Bed, starts with trough cross-bedded or massive, poorly sorted medium- to coarse-grained sandstones that show highly variable transport directions (Pl. 1: 3). They are overlain by small-scale crossbedded or ripple cross-bedded sandstones and by minor silt- and claystones with flaser or lenticular bedding that includes small sandstone lenses (Pl. 1: 4). The fine-grained sediments are repeatedly dissected by poorly sorted, conglomeratic sandstone horizons with mud clasts, reworked concretions, megaripple surfaces and/or skeletal concentrations of thick-shelled bivalves (see below; Pl. 1: 5). The troughs of megaripple surfaces are commonly filled with finegrained sediment. Medium- to coarse-grained, trough cross-bedded sandstones dominate the upper part of the Trigonia smeei Bed. Northeast and southwest of Tendaguru, the sandstones interfinger with oolitic limestones.

\section{Invertebrates}

A prominent feature of the macroinvertebrate fauna is the occasional concentration of bivalves in shell beds. Most conspicuous are mono- to paucispecific skeletal concentrations dominated by large and thick-shelled individuals of shallow infaunal trigoniid (PI. 2: 3) and astartid bivalves (e.g., Tin 9m, Mai 5, Mai 7, Dwa 01; see also Dietrich 1933). The valves are almost invariably disarticulated, but not fragmented, preferentially orientated in a convex-up position and typically lack signs of encrustation and bioerosion. Somewhat more diverse fossil assemblages (e.g., Tin $9 \mathrm{~g}$, Tin 9k), which in addition to trigoniids may contain oysters and other bivalves, gastropods, serpulids and corals, are regarded as a variation of this type of shell bed.

A second type of skeletal concentration is associated with fine-grained, horizontally to low-angle cross-bedded sandstones (e.g., Tin 9i, Kor 10, 12), where the lamination reflects subtle changes in grain size. Thin shell pavements of small, singlevalved bivalves occur preferentially in the slightly coarser grained laminae. Dominant taxa include Meleagrinella, small oysters, Protocardia, Entolium and Limea. The preferred orientation of valves in such pavements is either convex-up or convexdown. Between pavements, the same assemblage may occur scattered within the sediment.

A mixed siliciclastic-oolitic horizon approximately $8 \mathrm{~km}$ northwest of Tendaguru (Kor 24, 


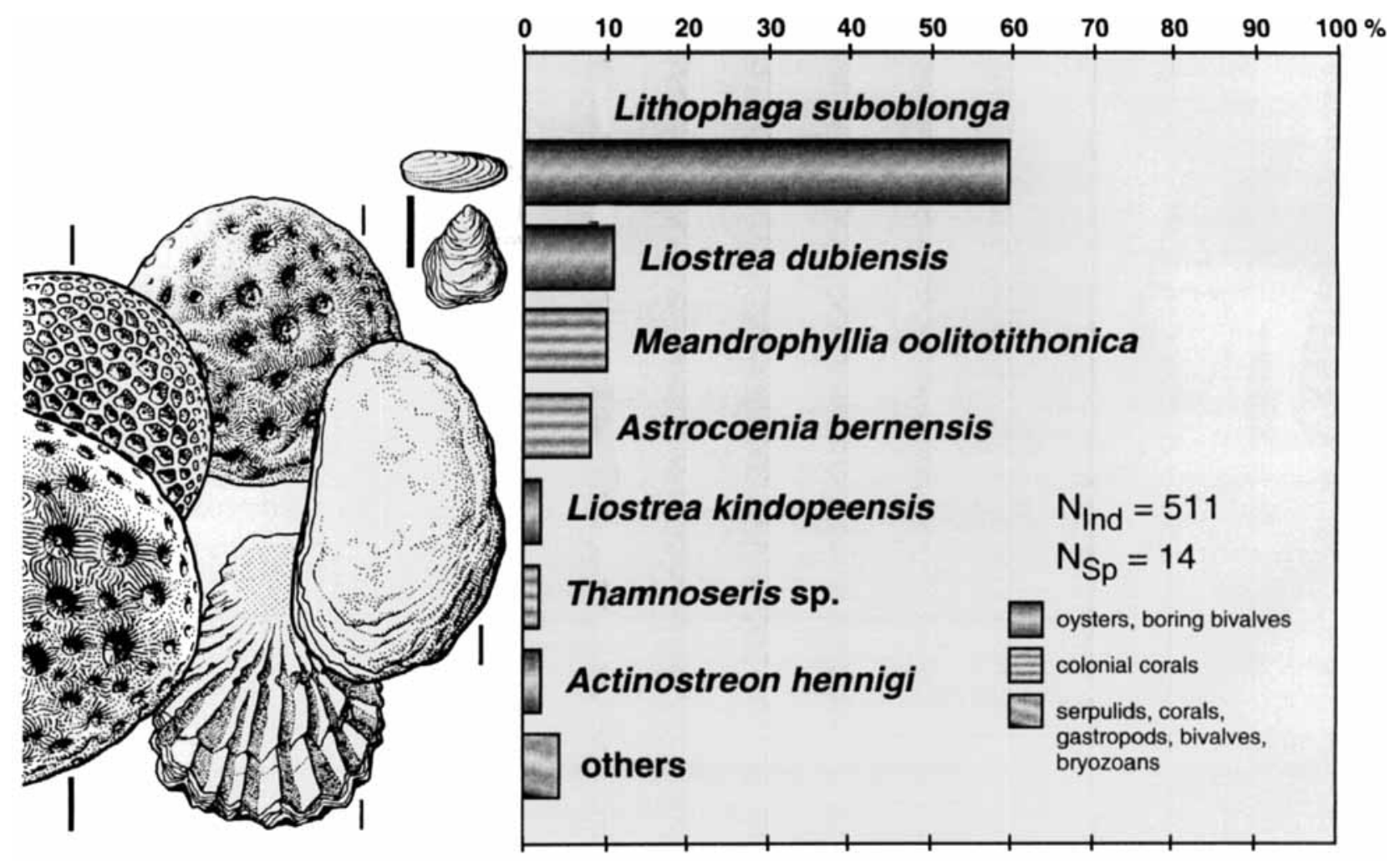

Fig. 5. Faunal composition and relative abundance of macroinvertebrates in sample Kor 24. Scale bars equal $1 \mathrm{~cm}$. For key of abbreviations see Fig. 3.

Fig. 1) is characterised by concentrations of colonial corals (e.g., Pl. 2: 6) that are up to $20 \mathrm{~cm}$ in diameter and largely occur in life position. Also common are large, thick-shelled cementing oysters (Fig. 5). Corals and thick-shelled oysters served as hard substrates for small cementing oysters and provided an ideal substrate for the boring bivalve Lithophaga. The latter, along with crowded juveniles of cementing oysters, dominate the assemblage in terms of relative abundance but, compared to corals, contributed little to the estimated biovolume of the assemblage. The level of fragmentation of corals and molluscs is remarkably low.

The calcareous microfauna of the Trigonia smeei Bed is represented by moderately diverse assemblages of ostracods and benthic foraminifera (samples Kin 2a, Tin 9j, Tin 9p/3, Tin 9/p5, Tin $9 \mathrm{qb}$, Tin 9r). Among ostracod genera identified so far Majungaella is common. The preservational state of the calcareous microfauna, mainly due to weathering and/or recrystallization, is poor to moderate.

\section{Vertebrates}

With the exception of a fragmentary vertebra of an indeterminate teleost fish in sample Tin $9 \mathrm{n} / \mathrm{o}$
(Arratia et al. 2002), no other vertebrate material was found during field work by the German and German-Tanzanian Tendaguru expeditions.

Flora

The majority of palynologically useful samples from the Tendaguru succession are from this unit (Tin 9f to Tin 9r). All samples contain marine dinoflagellates (e.g., Pl. 1: 7) occasionally including chorate forms. Other organic-walled microfossils of marine origin include "chitinous" microforaminifera (organic linings of tests of small foraminifera in Tin $9 f$ and Tin 9h/2) and acritarchs (Micrhystridium in Tin 91). In addition, the freshwater alga Ovoidites occurs in Tin 91, and Tin $9 p / 5$ yielded moderately well-preserved specimens of the charophyte genus Clavator.

The mesoflora also reaches its highest diversity within this section and is particularly concentrated in samples Tin $9 \mathrm{~h}, 9 \mathrm{j}, 9 \mathrm{p}$ and $9 \mathrm{q}$. Apart from three types of Cheirolepidiaceae, cuticles of Cycadales and pteridosperms of Dicroidium- or Pachypteris-type are present. Abundant fusain represents three types of podocarpacean wood, two species of Glyptostroboxylon (e.g., Pl. 2: 13), one species of Platyspiroxylon and an as yet undescribed araucarian wood. 


\section{Environmental interpretation}

The coarse-grained sandstones with highly variable transport directions are interpreted as large tidal channel deposits (Pl. 1: 3). Grain-size, large-scale sedimentary structures and lack of trace fossils indicate a high-energy regime and frequent reworking. This resulted in a highly mobile substrate, which probably was responsible for the complete absence of epifaunal and infaunal elements.

The overlying cross-bedded sandstones and minor silt- and claystones with flaser or lenticular bedding represent tidal flat deposits and associated tidal channel fills (Pl. 1: 4). Pavements of small, single-valved bivalves in horizontally to low-angle cross-bedded, fine-grained sandstones were formed, apparently, by tidal currents in small flood and ebb tidal deltas and along the beach.

The taphonomic signatures of shell concentrations in coarse-grained sediments suggest episodic exhumation of infaunal individuals and relatively rapid redeposition as is typical of highenergy events such as storms (see also Dietrich 1933). The erosive base of shell beds is also consistent with a storm-induced origin. The lack of articulated bivalves can be explained by the reworking of dead individuals only. Size sorting and the hydrodynamically stable convex-up position of most shells point to post-mortem transport of shells and the presence of currents at the time of deposition. Long distance transport, however, is not likely to have occurred, as indicated by taphonomic features such as the low degree of fragmentation. Storm beds have their highest preservation potential between fair weather wave base and storm wave base. Sedimentological evidence indicates that the various sediments of the Trigonia smeei Bed were deposited above fair weather wave base. In such shallow marine environments it is not surprising that original concentrations of hard parts by storm processes subsequently were modified by currents. The coarse-grained, poorly sorted horizons lacking shell beds and overlain by fine-grained sediment apparently represent couplets typical of tempestites.

The upper part of the Trigonia smeei Bed again represents tidal channel and sand bar deposits. The oolitic limestones with which they interfinger resemble modern ooid sands and obviously formed as high-energy ooid shoals. Adaptation to relatively high turbulence levels can also be seen in the coral-oyster bed that is associated with mixed siliciclastic-oolitic sediments, as demonstrated by the massive growth forms of corals, high percentage of cementing elements and extraordinarily thick shells of oysters, other bivalves and some gastropods. The marked dominance of epifauna and presence of cementing oysters and serpulids within the sediment points to a firm and stable substrate. Sedimentation rates seem to have been low, as indicated by the relatively high degree of bioerosion and encrustation. Corals and oysters did not form a distinct relief on the sea floor, but only low thickets. All in all, the sample is characteristic of an autochthonous coral-oyster biostrome that colonized a stable substrate within a waveand/or current-influenced, normal marine and shallow water environment.

A predominantly marine environment of the Trigonia smeei Bed is also evident from calcareous microfossils and from palynological data, as indicated by the abundant marine ostracods, benthic foraminifera, dinoflagellates and, less commonly, by organic-walled microforaminifera and acritarchs, which are usually interpreted as indicative of shallow marine environments (e.g., Sarjeant and Taylor 1999). On the other hand, the abundance of Classopollis and a diverse mesoflora suggests proximity to a vegetated hinterland dominated by members of the xerophytic conifer family Cheirolepidiaceae and acting as a source of plant material. For a single sample (Tin 9p/5), the charophyte genus Clavator indicates freshwater influence (M. Schudack, pers. comm.).

\section{Upper Saurian Bed}

\section{Facies}

The basal part of the Upper Saurian Bed consists of small-scale cross-bedded and ripple crossbedded, fine-grained sandstones and siltstones with intercalations of isolated micritic dolomite layers. These sediments are overlain by ripple cross-bedded and small-scale cross-bedded, finegrained sandstones and by claystones.

\section{Invertebrates}

With few exceptions, the Upper Saurian Bed is devoid of macroinvertebrates. A low diversity assemblage, very rich in articulated shells of Eomiodon cutleri (e.g., Pl. 2: 2), occurs in the lower part of the Upper Saurian Bed at Kitukituki (Tin So1), and a monospecific assemblage of abun- 
dant articulated juveniles of $E$. cutleri was sampled from the base of the unit at Dwanika (Dwa A). A few meters up-section (Dwa 5a, 5b) rare juveniles of Meleagrinella, Eomiodon and gastropods occur, and a single valve of Falcimytilus dietrichi (Pl. 2: 1) was found in sample Dwa 6b/1. Samples Dwa $5 b, 6 c$ and $7 b$ yielded a few poorly preserved ostracods, of which only one taxon, Cypridea sp., could be more precisely identified from Dwa $5 b$.

\section{Vertebrates}

The most common fish remains from the Upper Saurian Bed are isolated scales and teeth of Lepidotes tendaguruensis (Arratia et al. 2002). Several fairly complete specimens of this taxon were described by Arratia \& Schultze (1999), and a mass accumulation of $L$. tendaguruensis reported from site M (Hennig 1914b, Arratia \& Schultze 1999) merits special mention. Selachians (Sphenodus sp.; e.g., Pl. 2: 11), a pycnodontid and other unidentified fish remains were previously recognized by Hennig (1914b). Additional collecting in the Dwanika stream section (Dwa 5a) yielded several selachian taxa previously unknown from the Tendaguru Beds, including three hybodonts (Hybodus sp., Hybodontidae indet., Lonchidion sp.; see also Pl. 2: 10) and the new neoselachian batoid Engaibatis schultzei (Arratia et al. 2002).

The sauropods include Brachiosaurus brancai, Janenschia robusta, Dicraeosaurus sattleri and Barosaurus africanus (Janensch 1961). Fossiliferous deposits exposed at Nambango (approximately $15 \mathrm{~km}$ southeast of Tendaguru Hill) that probably belong to the Upper Saurian Bed yielded two anterior dorsal vertebrae of a sauropod assigned to Tendaguria tanzaniensis (Bonaparte et al. 2000). The ornithischians are represented by Kentrosaurus aethiopicus, the theropods by Elaphrosaurus bambergi, 'Megalosaurus ingens', 'Labrosaurus stechowi' and 'Ceratosaurus roechlingi' (Janensch 1925b, see also Table 2).

The Upper Saurian Bed exhibits the same principal preservational categories of dinosaurs as the Middle Saurian Bed. Incomplete skeletons (e.g., Barosaurus africanus, site k), partial skeletons (e.g., Janenschia robusta, site G), bone fields (e.g., Kentrosaurus aethiopicus, site X) and solitary bones have been found (Heinrich 1999a). Disarticulated skeletal assemblages of sauropods appear to be the most common type. Single-individual bone assemblages (e.g., site cc: Brachiosaurus brancai) and multi-individual assemblages (e.g., site P: Janenschia robusta), as well as single-taxon assemblages (e.g., site O: Dicraeosaurus sattleri; site k: Barosaurus africanus) and multi-taxon assemblages (e.g., site ab: B. brancai ?, $D$. sattleri, $B$. africanus, Sauropoda indet.) have been documented by the GTE (Heinrich 1999a). Most of the sauropod bone assemblages appear to represent single-individual assemblages. The Barosaurus africanus bone assemblages recovered from the Upper Saurian Bed are dominated by adult and old adult individuals (Heinrich 1999a). Of special interest are vertically oriented, articulated fore feet of Janenschia robusta (site 5) and Brachiosaurus brancai (site R) as well as articulated hind feet of Barosaurus africanus from sites XIII and 28 (Janensch 1914c, 1961).

Isolated teeth of crocodiles were also found at site Z (Janensch, unpublished). Many pterosaur bones, originally described by Reck (1931), were based on non-diagnostic elements and have recently been identified as indeterminate dsungaripteroids (Unwin \& Heinrich 1999). Noteworthy is a mass accumulation of postcranial pterosaur bones reported from site MD (Reck 1931).

The poorly preserved dentary of Brancatherulum tendagurense (Dietrich 1927) from site IV documents the presence of eupantotherian mammals. The sediments that yielded this specimen have been recently identified as channel lag deposits. Additional microvertebrate material was recently collected in the Dwanika stream section (Heinrich et al. 2001). Several samples have yielded teeth of a dwarf crocodile (Bernissartia sp.; e.g., Dwa 6b/1), teeth and jaw fragments of supposed sphenodontid lepidosaurs (e.g., Dwa A), and a tiny dentary fragment of a mammal (Dwa 6b/1) that is too poorly preserved for detailed taxonomic identification (Heinrich et al. 2001). Many microvertebrate remains are indeterminable because of their poor state of preservation.

A remarkably similar vertebrate fauna was recovered from the transitional sands overlying the Trigonia smeei Bed, here considered as the base of the Upper Saurian Bed. Dinosaurs are mainly represented by isolated limb bones of Brachiosaurus brancai, Barosaurus africanus, Barosaurus gracilis (Janensch 1961) and Kentrosaurus aethiopicus (Hennig 1925). Tendaguru site MD produced many pterosaur remains embedded close to a vertebral column of Barosaurus africanus (Reck 1931). Hennig (1914b) reported four teeth of the neoselachian Sphenodus sp. recovered from the base of the Upper Saurian Bed at site 
Om, and teeth of an indeterminate crocodile were found at the same locality (Janensch, unpublished).

\section{Flora}

Most samples from this unit are palynologically barren or contaminated by Recent or sub-Recent palynomorphs (Rhizophagites assemblage). One sample (Dwa 5base) has yielded a small Mesozoic palynoflora dominated by Classopollis, as well as Araucariacites and a bisaccate as subordinate components. No marine palynomorphs were observed, but charophytes are present in Dwa $6 \mathrm{~b}, 6 \mathrm{c}$ and $7 \mathrm{~b}$.

A few cuticle specimens of the Cheirolepidiaceae and a single cuticle of araucarian type were recovered. Wood, represented by a limited amount of well-preserved fusain in Dwa 7, is referred to Glyptostroboxylon and the undescribed araucarian wood type already mentioned from the Trigonia smeei Bed.

\section{Environmental interpretation}

As for the Middle Saurian Bed, most of the sediments of the basal Upper Saurian Bed are thought to represent tidal flat deposits. The micritic dolomites can be attributed to a mixing-zone or supratidal evaporitic dolomitization. The remarkably high degree of articulation of faunal assemblages dominated by $E$. cutleri demonstrates that post-mortem transport of shells was not significant in these samples. The close correspondence in composition and structure to the Eomiodon assemblages from the Middle Saurian Bed suggests similar environmental conditions, in particular environmental stress induced by fluctuating and/or lowered salinities that occurs, for example, in brackish water ponds. The influence of freshwater is also compatible with the rare occurrences of charophytes and the ostracod genus Cypridea. The presence of marine invertebrates, albeit sporadic, suggests proximity to the sea.

The unfossiliferous sandstones in the upper part of the unit were most probably deposited in tiny fluvial channels in a coastal plain environment, whereas the argillaceous deposits are thought to have formed in small lakes and pools.

The selachian association from Dwa 5a, dominated by three hybodont taxa and a single batoid, is considered here as typical of nearshore environments (hybodont-batoid association), and hybodonts clearly outnumber all other selachian taxa in these associations. Late Jurassic to Early Cretaceous hybodonts have been reported from a wide variety of environments ranging from marine to non-marine. This indicates that hybodonts could tolerate wide ranges of salinity and, by Late Jurassic times, were, in some cases, adapted to brackish and fresh water conditions in coastal habitats (e.g., Patterson 1966, Duffin 1985, Duffin \& Thies 1997).

The environmental adaptations of fossil neoselachians are controversial. Generally, fossil neoselachians are supposed to be absent from true brackish or fresh water deposits (Thies 1995). Late Jurassic batoids, however, are the dominant faunal elements in several Kimmeridgian and Tithonian neoselachian faunas from northwestern France and England, and have been interpreted as having occurred in restricted lagoonal environments (Candoni 1995, Underwood \& Ward in press). A selachian assemblage containing only hybodonts and batoids, but no other neoselachians has been reported from the Purbeckian of southern England (Underwood \& Rees in press), and is interpreted as a typical fauna of restricted environments. Typical Cretaceous near- and/or in-shore selachians are orectolobiforms, sclerorhynchids and small batoids (e.g., Williamson et al. 1993). Extant sharks and rays are quite common in tidal marshes and tidal swamps, and, for example, are represented by several species of orectolobiforms, carcharhinids (including large specimens of hammerheads and tiger sharks), and rays. The fossil neoselachian Sphenodus has no Recent analogue. Hennig (1914b) interpreted this shark as a scavenger, and Thies \& Reif (1985) characterised it as a slow swimming, near bottom predator. Altogether, the Tendaguru selachian fauna represents an assemblage typical of marginal marine to inshore environments, and its abundant hybodonts as well as the numerous remains of the bony fish Lepidotes were well adapted to cope with reduced salinities and salinity fluctuations.

The terrestrial vertebrates of the Upper Saurian Bed are characterised by an even more diverse assemblage of herbivorous sauropods than that from the Middle Saurian Bed. Again, there are high-browsers (e.g., Brachiosaurus brancai) and low-browsers (Kentrosaurus aethiopicus). The abundance of disarticulated skeletons suggests considerable pre-burial carcass decay. With respect to the upright, articulated fore and hind feet, Janensch (1914b: 249) supposed that these sauropods became mired in the mud of shallow water lagoons. He suggested that they temporarily entered such lagoons during low tides where they became trapped in the mud and killed by the returning sea. The foot bones remained in 
the mud, whereas the remaining parts of the carcasses were dispersed by wave action or waveinduced currents. The unusual upright burial of foot bones testifies to their autochthony and demonstrates conclusively that at least some large sauropods inhabited or certainly visited the Tendaguru coastal plains. This is consistent with numerous reports of sauropod tracks around large water bodies (e.g., Lockley 1991), demonstrating that sauropods visited these environments.

Mass accumulations of bones of Kentrosaurus aethiopicus at site $\mathrm{X}$ were originally interpreted as evidence of sudden mass death events (Janensch 1914b, Hennig 1925; cf. Middle Saurian Bed). However, no sedimentological indicators for catastrophic events have so far been found in the Upper Saurian Bed. Therefore, "normal" annual input of bones might well have been responsible for this type of bone accumulation.

Several theropod species lived alongside the herbivorous dinosaurs, among them the mediumsized, agile Elaphrosaurus bambergi and heavybuilt predators ('Megalosaurus ingens', 'Ceratosaurus roechlingi'). The small mammal Brancatherulum tendagurense and the sphenodontid lepidosaurs were terrestrial while the air was dominated by pterosaurs. Crocodiles had a semiaquatic lifestyle and most likely fed on fish and other vertebrates.

As the occurrence of herbivorous dinosaurs is essentially controlled by vegetation, the greater diversity of sauropods "suggests that a greater diversity of vegetational growth and growth levels were being tapped" (Russell et al. 1980: 172). Composition of the flora indicates that a Cheirolepidiaceae-dominated terrestrial vegetation continued to exist throughout the time of deposition of the Upper Saurian Bed, but little can be said about the actual diversity or composition of niches. It is important to note that the environments represented by the Middle and Upper Saurian Beds were, at best, only poorly vegetated and do not correspond to the feeding grounds of herbivorous dinosaurs. However, the plant remains transported into the environments of the Saurian beds and inferences regarding the feeding habits of dinosaurs make it possible to deduce indirectly some characteristics of the vegetated hinterland.

\section{Trigonia schwarzi Bed}

\section{Facies}

In the Tendaguru area, only the basal part of the Trigonia schwarzi Bed is preserved. The unit starts with a conglomerate horizon that overlies an erosional contact. The succeeding trough cross-bedded or ripple cross-bedded, medium- to fine-grained sandstones form small fining-upward sequences. These in turn are overlain by ripple cross-bedded, horizontally bedded or bioturbated, fine-grained sandstones, siltstones and claystone.

\section{Invertebrates}

Apart from a few disarticulated shells of Trigoniid bivalves found in coarse-grained sediments, no invertebrate fauna was found on the top of Tendaguru Hill. Lange (1914) and Dietrich (1933) reported bivalve accumulations, dominated by Tancredia tellina, from poorly cemented sandstones.

\section{Vertebrates}

The only known vertebrate fossils from the Trigonia schwarzi Bed were found at some distance from Tendaguru Hill. They comprise the tooth of a pycnodontid fish collected at locality 25 (Mikadi) and an indeterminate selachian spine from site 32 (Nambawala, Pilepile) (Hennig 1914b).

\section{Flora}

The Trigonia schwarzi Bed yielded two palynologically productive samples (Nam 1a, b) from the Namunda Plateau a few kilometers south of Tendaguru Hill. Marine dinoflagellates are rare, and among the land-derived sporomorphs Classopollis (Cheirolepidiaceae) continues to be the most common form. Pteridophytic spores are characterised by the appearance of striate (Cicatricosisporites) and spinose types. Data on plant mesofossils are not yet available.

\section{Environmental interpretation}

The fining upward sequences are interpreted as tidal channel fills, whereas the fine-grained sandstones to claystones are thought to represent tidal flat deposits. Clearly, further palaeoenvironmental analyses of coeval strata are necessary to better understand the environments and habitats represented by the Trigonia schwarzi Bed.

The spore assemblage reflects a change in the composition of the terrestrial vegetation and the appearance of humidity-loving ferns with affinity to the Schizaeaceae. 


\section{Palaeoenvironmental discussion}

\section{Previous interpretations}

According to Janensch (1914b) the depositional environments of the Saurian beds were shallow water lagoons, in which sedimentation was affected by tides, hurricans, waves and earthquakes. Dietrich (1925) and Reck (1925) envisaged a low-relief coastal plain with extended swamps or coastal lagoons. Dietrich (1933) interpreted the Saurian beds as lagoonal-estuarine deposits, while Reck (1925) argued for a deposition in hypersaline lagoons or saline marshes.

Conversely, Fraas (1908), Schuchert (1918), Abel (1927), Parkinson (1930) and Colbert (1984) believed that an estuarine environment with rivers and deltas existed in what is now the Tendaguru area. The dinosaurs lived primarily on land and along river banks and adjacent regions possibly including "brackish water marshes along the coast and rivers" (Schuchert 1918: 275). Carcasses of drowned or killed dinosaurs floated downstream in rivers that meandered through coastal lagoons, and the carcasses were buried close to the mouths of rivers.

By contrast to the assumption of an estuarine or deltaic environment for the Saurian beds, we found no indicators for the existence of major fluvial systems in the Tendaguru area. Deposits typical of large fluvial or distributary channels are missing, as are other sediments characteristic of deltas, such as distributary mouth bar sands or subaqueous slump deposits (Coleman \& Prior 1982, Elliott 1986). Furthermore, coarsening-upward sequences, typical of delta deposits, are not developed, and the sediments generally become finer grained towards the shoreline. This argues against the presence of a major sediment source in the direct hinterland of the Tendaguru region and favours transport parallel to the shoreline for the relatively coarse-grained sandstones of the Nerinea, the Trigonia smeei and the Trigonia schwarzi Bed. Similarly, deposits typical of estuaries are missing. Consequently, the assumption of a major river coming from the hinterland and entering the sea in the Tendaguru region must be rejected, and long-distance transport of large vertebrate carcasses in rivers, as suggested by Schuchert (1918), is unlikely. Nevertheless, the occurrence of small-scale channel fills in the Upper Saurian Bed indicates the existence of some minor river systems in the coastal plain. These rivers might have transported some small vertebrate-carcasses from the continental into the marine environment and acted as favourable sites for the accumulation of vertebrate remains.

Our model (see below) favours a palaeoenvironmental setting that is basically similar to that proposed by Dietrich (1925) and Reck (1925) in so far as its marine aspects are reminiscent of a large lagoon that formed behind barriers. Landward, the extended tidal flats bordering the lagoon gradually passed into a low-relief coastal plain environment with lakes, pools and small fluvial channels. However, sedimentary indicators for hypersaline conditions (evaporite minerals, evaporite pseudomorphs, intense mudcracks), as proposed by Reck (1925), were not found. Similarly, in contrast to Dietrich (1925), indicators for the existence of swamps (root traces, paleosols with indicators of waterlogging, coal seams) are also missing.

\section{A refined model for the Tendaguru Beds}

Litho- and biofacies of the Tendaguru Beds indicate a marginal marine setting, composed of (1) lagoon-like, shallow marine environments; (2) extended siliciclastic tidal flats and low-relief coastal plains; and (3) vegetated hinterlands. These three environmental sub-units are discussed in more detail below (Fig. 6):

\section{Lagoon}

Based on our sedimentological, taphonomic and palaeoecological observations, the Nerinea Bed, Trigonia smeei Bed and Trigonia schwarzi Bed probably represent a lagoon-like, coastal, shallow marine environment above fair weather wave base that was affected by tides and storms. The lagoon was separated from the open sea by barriers such as ooid bars, sand bars or sandy barrier islands. With its effective tidal passes, strong tidal currents and adjacent tidal flats, it probably resembled an extensive "leaky lagoon" (Kjerfve \& Magill 1989). Water agitation ranged from moderately high on lower tidal flats to very high in tidal channels, sand bars and reworked horizons. Clearly, energy levels were sufficiently high to keep food particles in suspension, as is demonstrated by the dominance, throughout, of suspension-feeders. The general absence or scarcity, at least during most periods, of stenohaline higher taxa such as ammonites, articulate brachiopods, in situ corals and echinoderms is striking. This points to salinity conditions that deviated from the normal marine condition. Salinity reductions or fluctuations, however, seem to have been of 


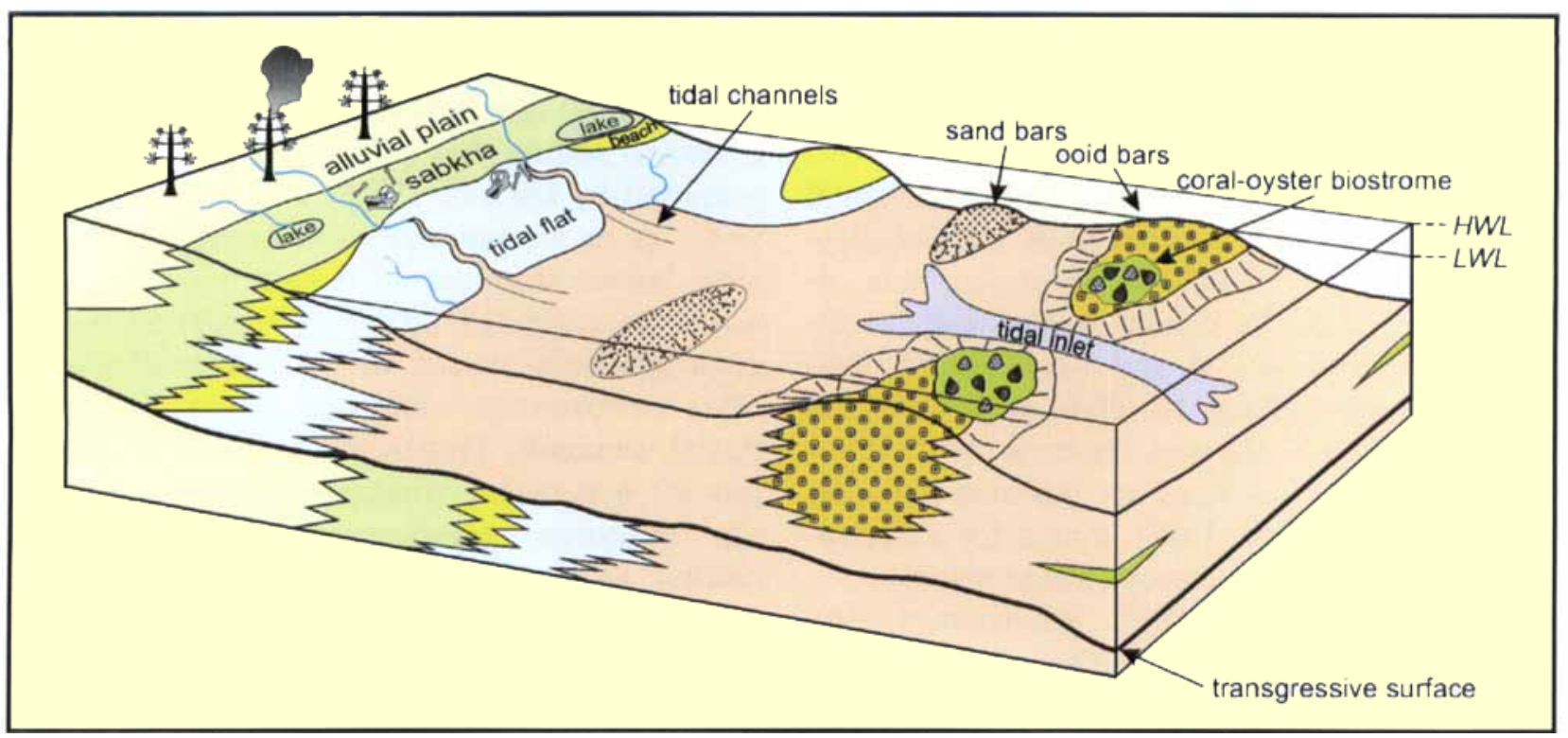

Fig. 6. Environmental model of the Tendaguru Beds at their type locality. HWL $=$ high water line; $\mathrm{LWL}=$ low water line. For discussion see text.

minor extent as is indicated by the moderately high diversity of macro- and microinvertebrates. By contrast, normal marine salinities are likely for the coral-oyster biostrome (Trigonia smeei Bed) at some distance from Tendaguru and in the basal part of the Nerinea Bed.

\section{Tidal flats and coastal plains}

The fine-grained sediments of the Lower, Middle and Upper Saurian Beds and their biota are interpreted as representing largely intertidal deposits and low-energy coastal lakes and ponds. In part, continental conditions also prevailed, such as sabkha-like coastal plains with lakes and pools, some of which seem to have dried up periodically and small fluvial channels. High densities of Eomiodon in very low diversity assemblages occur at various levels within the sequence, most commonly at the base of the Middle and Upper Saurian Beds. They reflect environmental stress related to abnormal salinity conditions. Considering the marked seasonality of the climate (see below), seasonally fluctuating salinity values are assumed rather than a relatively constant reduction of salinities over longer periods of time. These salinity fluctuations may have been due to freshwater influx from the land in areas adjacent to the Tendaguru area, heavy seasonal rainfall, or a combination of both.

These are also the environments in which the large vertebrate remains are preserved. However, both tidal flats and marginal areas of the coastal plains apparently lacked substantial vegetation. Although all the palaeobotanical remains come from marine influenced sediments there is no evidence of salt-tolerance by any of the fossil plants found at Tendaguru. Therefore, the feeding habitats and place of final burial of large terrestrial vertebrates do not coincide. We envisage periods of seasonal drought that drastically reduced the wide variety of vegetational food resources in the Tendaguru hinterland. As a consequence, the herbivorous dinosaurs left their previously vegetated "home lands" and, followed by carnivorous dinosaurs, were forced to move to nearby coastal plains and tidal flats in search of food and water. In these apparently poorly vegetated environments, the animals were exposed more intensively to direct sunlight, but, at the same time, these areas most likely offered water holes that could be used as muddy wallows by dinosaurian megaherbivores (e.g., Brachiosaurus, Barosaurus, Dicraeosaurus) for thermoregulation, especially for dumping absorbed heat. Nevertheless, an increased mortality rate during periods of seasonal drought is to be expected. Therefore, wallows and ephemeral water bodies such as lakes and ponds might have acted as both refuges and die-off sites for migrating dinosaurs during periods of seasonal drought (Heinrich 1999a).

\section{Vegetated hinterland}

Vegetation in the hinterland can be inferred indirectly from plant material that was transported into the marginal marine system either by water or by wind. It is characterised by a diverse conifer flora, which, together with spore-producing 
plants, apparently formed part of the food source of the large herbivorous sauropods. The most important group are the Cheirolepidiaceae, which, by Late Jurassic times, are well known as a dominant element in forests bordering the sea as well as on better drained soils in the uplands (Alvin 1982). Further common elements of the flora comprise Podocarpaceae, Araucariaceae and yet undescribed conifers. Cycads and ginkgos are less commonly preserved. Undergrowth is more difficult to reconstruct and may be represented by shrub-like Cheirolepidiaceae, several pteridophytes (e.g., Pl. 1: 8) and by pteridosperms of the family Corystospermaceae.

According to climate models (see below), in the western direction the vegetated area passed into the dry interior of Gondwana. Obviously, this region was highly unfavourable as a refuge during periods of seasonal drought, and dinosaurs were more likely displaced eastward towards the sea.

\section{Vertical succession}

In vertical sequence, the Tendaguru Beds consist of three transgressive-regressive cycles. During transgressive periods, the coastal barrier systems migrated landward and caused large-scale reworking of tidal flat and coastal plain deposits. Subsequent regressive sequences demonstrate an almost complete succession from shallow subtidal sands to tidal flat and beach sediments, followed by sabkha-like coastal plain deposits (Bussert \& Aberhan 2001).

\section{Climate}

Information regarding the climate can be drawn from a variety of sources. The prevalence of siliciclastic sediments and reduced salinities, as deduced from the composition of fauna and microflora, reflect considerable freshwater input, either by rivers or by strong precipitation. By contrast, high amounts of feldspars in the sandstones, and the dominance of smectite and illite in the clay mineral fractions indicate a reduced intensity of chemical weathering. Furthermore, the presence of calcretes and supratidal dolomites provide evidence of dry periods under a warm to hot climate with seasonal rainfall. Higher potassium feldspar/plagioclase feldspar-ratios in the sandstones of the Trigonia schwarzi Bed, as compared to the Jurassic part of the sequence, might be related to an increase in chemical weathering and a more humid climate.
With respect to palaeovegetation, the conifer family Cheirolepidiaceae, represented in the Tendaguru Beds by both mesofossils and landderived palynofloras, is regarded as a thermophilous group with xerophytic adaptations (Watson 1988). The occurrence of growth rings demonstrates that climatic conditions varied frequently. For the Tendaguru climate, dry seasons are suggested by the extensive occurrence of fossil charcoal (see Batten 1975). On the other hand, abundance of as yet undescribed fungi infesting and degrading the wood requires wet conditions or at least increased humidity (Alvin et al. 1981). Seasonal humidity is also indicated by the occurrence of Glyptostrobus- and Podocarpus-related wood (Figueiral et al. 1999), which is present in all units of the Tendaguru Beds. Spores of the generally hygrophilous pteridophytes are rare and of relatively low diversity. The appearance in the Trigonia schwarzi Bed of Cicatricosisporites and related taxa signals a rather moderate diversification of pteridophytic spores during Early Cretaceous times. This is tentatively interpreted as a change towards slightly more humid conditions. In summary, a subtropical to tropical palaeoclimate, characterised by seasonal rainfall alternating with a pronounced dry season, prevailed throughout most of the depositional interval of the Tendaguru Beds. Mineralogical and palynological data from the Trigonia schwarzi Bed both seem to indicate a shift towards a more humid climate in Early Cretaceous times.

Generally, our results are in good agreement with results of other workers. Based on sedimentological and palaeontological evidence, Hallam (1985, 1993) proposed a dry climate for East Africa during the Late Jurassic, and climate predictions based on GCM simulations by Moore et al. (1992), Valdes \& Sellwood (1992) and Valdes (1994) suggested a strong seasonal precipitation for the region. In marked contrast, Uhmann (1996), who used lithological and mineralogical indicators, proposed a humid climate for southwestern Madagascar during the Upper Jurassic and argued for an exceptional climate ("klimatische Sonderstellung") for Madagascar during this interval.

\section{Conclusions}

Within the scope of an interdisciplinary analysis of the Tendaguru Beds (Late Jurassic to Early Cretaceous of Tanzania, East Africa), we utilized new sedimentological and palaeontological data 
to construct an environmental model for the Tendaguru Beds at their type locality. In our model we recognise three main palaeoenvironmental units: (1) tide- and storm-dominated, lagoon-like, shallow marine environments represented by the Nerinea, Trigonia smeei and Trigonia schwarzi beds. The various subenvironments comprise barriers such as ooid bar and siliciclastic sand bar complexes, tidal channels and tidal sand bars, flood and ebb deltas and beach sands. Generally, the lagoon was subject to minor salinity fluctuations. Landwards, the lagoon passed into (2) extended siliciclastic tidal flats and low-relief coastal plains that are largely represented by the three dinosaur-bearing successions, i.e. the Lower, Middle and Upper Saurian Beds. Subenvironments include low-energy, brackish coastal lakes and ponds, as well as pools and small fluvial channels in coastal plains. As the preserved parts of the coastal plain lack any signs of an autochthonous vegetation, the place of final burial and feeding grounds of large land-dwelling vertebrates do not coincide. Throughout much of their lives, dinosaurs apparently thrived in (3) a vegetated hinterland. The floral composition of the latter can only be inferred indirectly from plant material transported into the marine-influenced environments, and reconstruction is hampered by the selective preservation of only the most durable plant remains. This region of the Tendaguru palaeo-ecosystem was covered by a diverse conifer flora, which, along with cycads, pteridophytes and ginkgos, at least partly served to meet the immense food requirements of large sauropods. Various sedimentological and palaeontological features of the Tendaguru Beds suggest that these Late Jurassic sediments were deposited under a subtropical to tropical palaeoclimate, with seasonal rainfall alternating with a pronounced dry season. In Early Cretaceous times, climate seems to have shifted towards more humid conditions.

We regard our interpretations as a critical step towards a better understanding of the Tendaguru palaeo-ecosystems in Late Mesozoic times. Clearly, however, further detailed and multidisciplinary analyses within a broader geographical framework are needed to answer many important questions concerning the geology, biostratigraphy and sequence stratigraphy of the Tendaguru Beds, the genesis of vertebrate and invertebrate skeletal concentrations, the palaeobiology of the Tendaguru dinosaurs, and the various ecosystems represented in the Tendaguru Beds.

\section{Acknowledgements}

We would like to thank Abdul H. Mruma and Sospeter Muhongo from the Department of Geology of the University of Dar es Salaam for their participation in and support for the Tendaguru Expedition 2000. We wish to thank Oliver Hampe, Museum für Naturkunde, Gerhard Maier, Calgary, Emma Msaky, Tanzania Petroleum Development Corporation, Dar es Salaam, and Remigius Chami, Ministry of Natural Resources and Tourism, Antiquities Units, Dar es Salaam, for accompanying us in the field.

Many thanks go to Hans-Peter Schultze, Museum für Naturkunde, for supporting the project and presenting it to different German commissions. We are very grateful to Andrew R. Milner, London, for his help with the identification of microvertebrates (lissamphibians, sphenodontids). We thank Günter Schweigert, Staatliches Museum für Naturkunde Stuttgart, for the discussion of stratigraphic issues and Michael Schudack, Freie Universität Berlin, for the determination of charophytes. Photographic and graphic assistance was provided by Jörg-Peter Mendau, Carola Radtke and Elke Siebert, all Museum für Naturkunde.

This study was financially supported by grants from the Deutsche Forschungsgemeinschaft, which are acknowledged with gratitude. The research of JK has been supported by a Marie Curie Fellowship of the European Community program "Improving Human Research Potential and the Socioeconomic Knowledge Base" under contract number HPMFCT-2001-01310. Camping and technical equipment was donated by the firm of BIWAK, Berlin-Köpenick, and by the TOOL-CO firm, Berlin-Lichtenrade.

Finally, we would like to thank the reviewers Franz T. Fürsich, Universität Würzburg, Wolfgang Mette, Universität Innsbruck, and Dave Unwin, Museum für Naturkunde, for their comments on the manuscript.

\section{References}

Abel, O. 1927. Lebensbilder der Vorzeit. 637 pp., Fischer, Jena. Aitken, W. G. 1961. Geology and palaeontology of the Jurassic and Cretaceous of southern Tanganyika. - Geological Survey of Tanganyika Bulletin 31: 1-144.

Alvin K. L. 1982. Cheirolepidiaceae: biology, structure and paleoecology. - Review of Palaeontology and Palynology 37: $71-98$.

Alvin K. L., Fraser C. J. \& Spicer R. A. 1981. Anatomy and palaeoecology of Pseudofrenelopsis and associated conifers in the English Wealden. - Palaeontology 24: 759-778.

Arratia, G. \& Schultze, H.-P. 1999. Semionotiform fish from the Upper Jurassic of Tendaguru (Tanzania). - Mitteilungen aus dem Museum für Naturkunde Berlin, Geowissenschaftliche Reihe 2: 135-153.

Arratia, G., Kriwet, J. \& Heinrich, W.-D. 2002. Selachians and actinopterygians from the Upper Jurassic of Tendaguru, Tanzania. - Mitteilungen aus dem Museum für Naturkunde Berlin, Geowissenschaftliche Reihe 5: 205-228

Balduzzi, A., Msaky, W., Tricianti, E. \& Manum, S. B. 1992 Mesozoic Karoo and post-Karoo formations in the Kilwa area, southeastern Tanzania - a stratigraphic study based on palynology, micropalaeontology and well log data from the Kizimbani well. - Journal of African Earth Sciences 15: 405-427.

Bate, R. H. 1975. Ostracods from the Callovian to Tithonian sediments of Tanzania, East Africa. - Bulletin of the British Museum (Natural History), Geology 26 (5): 161-223.

Batten, D. J. 1975. Wealden palaeoecology from the distribution of plant fossils. - Proceedings of the Geologistś Association 85: 433-458. 
Bonaparte, J. F., Heinrich, W.-D. \& Wild, R. 2000. Review of Janenschia Wild, with the description of a new sauropod from the Tendaguru beds of Tanzania and a discussion on the systematic value of procoelous caudal vertebrae in the Sauropoda. - Palaeontographica A 256 (1-3): $25-76$.

Broschinski, A. 1999. Ein paramacellodides Lacertilier-Fragment aus dem Oberen Jura von Tendaguru/Tansania. Mitteilungen aus dem Museum für Naturkunde Berlin, Geowissenschaftliche Reihe 2: 155-158.

Bussert, R. \& Aberhan, M. 2001. Sedimentation and palaeoecology of a tide, storm and Tsunami(?)-influenced coast at a passive margin: an example from the Upper Jurassic-Lower Cretaceous of SE Tanzania. 2001 Margins Meeting, Kiel. Schriftenreihe der Deutschen Geologischen Gesellschaft 14: 36-37.

Butler, P. M. \& MacIntyre, G. T. 1994. Review of the British Haramiyidae (? Mammalia, Allotheria), their molar occlusion and relationships. - Philosophical Transactions of the Royal Society of London 345: 433-458.

Candoni, L. 1995. Deux faunes inédites de sélaciens dans le Jurassique terminal français - Premiers resultats stratigraphiques. - Trimestriel de la Société Géologique de Normandie et des Amis du Muséum du Havre 82: $29-49$.

Christian, A. \& Heinrich, W.-D. 1998. The neck posture of Brachiosaurus brancai. - Mitteilungen aus dem Museum für Naturkunde Berlin, Geowissenschaftliche Reihe 1: $73-80$.

Christiansen, P. 1995. Aspects of sauropod palaeobiology and phylogeny. -209 pp., Master of Science Thesis, Copenhagen.

Coffin, M. F. \& Rabinowitz, P. D. 1988. Evolution of the conjugate East African - Madagascar margins and the Western Somali Basin. - Geological Society of America Special Paper 226: 78 pp.

Colbert, E. H. 1984. The great dinosaur hunters and their discoveries. - 283 pp., Dover Publications Inc., New York.

Coleman, J. M. \& Prior, D. B. 1982. Deltaic environments of deposition. In Scholle, P. A. \& Spearing, D. (eds). Sandstone Depositional Environments. - American Association of Petroleum Geologists, Memoir 31: 139-178.

Cox, L. R. 1965. Jurassic Bivalvia and Gastropoda from Tanganyika and Kenya. - Bulletin of the British Museum (Natural History), Geology, Supplement 1: 3-213.

Currie, P. J. 1997. Theropods. In Farlow, J. O. \& Brett-Surman, M. K. (eds). The Complete Dinosaur: 216-233, Indiana University Press, Bloomington and Indianapolis.

Dietrich, W. O. 1914. Die Gastropoden der Tendaguruschichten, der Aptstufe und der Oberkreide im südlichen Deutsch-Ostafrika. - Archiv für Biontologie 3 (4): $101-153$.

- 1925. Über eine dem mittleren Sauriermergel am Tendaguru äquivalente, rein marine Kimmeridgebildung in Mahokondo, Deutsch-Ostafrika. - Palaeontographica, Supplement 7, 2. Reihe (1): 1-24.

- 1926. Steinkorallen des Malms und der Unterkreide im südlichen Deutsch-Ostafrika. - Palaeontographica, Supplement 7, 2. Reihe (1): 41-102.

- 1927. Brancatherulum n. g., ein Proplacentalier aus dem obersten Jura des Tendaguru in Deutsch-Ostafrika. Centralblatt für Mineralogie, Geologie und Paläontologie, B 10: 423-426.

- 1933. Zur Stratigraphie und Palaeontologie der Tendaguruschichten. - Palaeontographica, Supplement 7, 2. Reihe (2): 1-86.

Duffin, C. J. 1985. Revision of the hybodont selachian genus Lissodus Brough (1935). - Palaeontographica A 188: $105-152$.

Duffin, C. J. \& Thies, D. 1997. Hybodont shark teeth from the Kimmeridgian (Late Jurassic) of northwestern Germany. - Geologica et Palaeontologica 31: 235-256.
Elliott, T. 1986. Deltas. In Reading, H. G. (ed.). Sedimentary Environments and Facies: 113-154, Blackwell Scientific Publications, Oxford.

Figueiral, I., Mosbrugger, V., Rowe, N. P., Ashraf, A. R., Utescher, T. \& Jones, T. P. 1999. The Miocene peat-forming vegetation of northwestern Germany: an analysis of wood remains and comparison with previous palynological interpretations. - Review of Palaeontology and Palynology 104: 239-266.

Fraas, E. 1908. Ostafrikanische Dinosaurier. - Palaeontographica 55: 105-144.

Fürsich, F. T. 1994. Palaeoecology and evolution of Mesozoic salinity-controlled benthic macroinvertebrate associations. - Lethaia 26: 327-346.

Hallam, A. 1976. Stratigraphic distribution and ecology of European Jurassic bivalves. - Lethaia 9: 245-259.

- 1985. A review of Mesozoic climates. - Journal of the Geological Society, London 142: 433-445.

- 1993. Jurassic climates as inferred from the sedimentary record. - Philosophical Transactions of the Royal Society of London B 341: 287-296.

Heinrich, W.-D. 1998. Late Jurassic mammals from Tendaguru, Tanzania, East Africa. - Journal of Mammalian Evolution 5 (4): 269-290, New York.

- 1999a. The taphonomy of dinosaurs from the Upper Jurassic of Tendaguru (Tanzania) based on field sketches of the German Tendaguru Expedition (1909-1913). - Mitteilungen aus dem Museum für Naturkunde Berlin, Geowissenschaftliche Reihe 2: 25-61.

- 1999b. First haramiyid (Mammalia, Allotheria) from the Mesozoic of Gondwana. - Mitteilungen aus dem $\mathrm{Mu}$ seum für Naturkunde Berlin, Geowissenschaftliche Reihe 2: $159-170$.

- 2001. New records of Staffia aenigmatica (Mammalia, Allotheria, Haramiyida) from the Upper Jurassic of Tendaguru in southeastern Tanzania, East Africa. - Mitteilungen aus dem Museum für Naturkunde Berlin Geowissenschaftliche Reihe 4: 239-255.

Heinrich, W.-D., Bussert, R., Aberhan, M., Hampe, O., Kapilima S., Schrank, E., Schultka, S., Maier, G., Msaky, E., Sames, B. \& Chami, R. 2001. The German-Tanzanian Tendaguru Expedition 2000. - Mitteilungen aus dem Museum für Naturkunde Berlin, Geowissenschaftliche Reihe 4: $223-237$.

Hennig, E. 1914a. Die Invertebraten-Fauna der Saurierschichten am Tendaguru. - Archiv für Biontologie 3 (4): $155-185$.

- 1914b. Die Fischreste unter den Funden der TendaguruExpedition. - Archiv für Biontologie 3 (4): 295-312.

- 1915. Kentrosaurus aethiopicus, der Stegosauride des Tendaguru. - Sitzungsberichte der Gesellschaft Naturforschender Freunde zu Berlin 1915: 219-247.

- 1925. Kentrurosaurus aethiopicus: die Stegosaurierfunde vom Tendaguru, Deutsch-Ostafrika. - Palaeontographica, Supplement 7, 1. Reihe (1): 100-253.

- 1937. Der Sedimentstreifen des Lindi-Kilwa-Hinterlandes. - Palaeontographica, Supplement 7, 2. Reihe (2): 99-186.

Huckriede, R. 1967. Molluskenfaunen mit limnischen und brackischen Elementen aus Jura, Serpulit und Wealden NW-Deutschlands und ihre paläogeographische Bedeutung. - Beihefte zum Geologischen Jahrbuch 67: 1-263.

Janensch, W. 1914a. Bericht über den Verlauf der Tendaguru-Expedition. - Archiv für Biontologie 3 (1): 17-58.

- 1914b. Die Gliederung der Tendaguru-Schichten im Tendaguru-Gebiet und die Entstehung der Saurier-Lagerstätten. - Archiv für Biontologie 3 (3): 227-261.

- 1914c. Übersicht über die Wirbeltierfauna der TendaguruSchichten, nebst einer kurzen Charakterisierung der neu aufgestellten Arten von Sauropoden. - Archiv für Biontologie 3 (1): 81-110.

- 1920. Über Elaphrosaurus bambergi und die Megalosaurier aus den Tendaguru-Schichten Deutsch-Ostafrikas. - 
Sitzungsberichte der Gesellschaft Naturforschender Freunde zu Berlin 1920: 225-235.

- 1925a. Die Grabungsstellen der Tendaguru-Gegend. Palaeontographica, Supplement 7, 1. Reihe (1): 17-19.

- 1925b. Die Coelurosaurier und Theropoden der Tendaguru-Schichten Deutsch-Ostafrikas. - Palaeontographica, Supplement 7, 1. Reihe (1): 1-97.

- 1955. Der Ornithopode Dysalotosaurus der Tendaguruschichten. - Palaeontographica, Supplement 7, 1. Reihe (3): $105-176$

- 1961. Die Gliedmaßen und Gliedmaßengürtel der Sauropoden der Tendaguruschichten. - Palaeontographica, Supplement 7, 1. Reihe (3): 177-235.

Kent, P. E., Hunt, J. A. \& Johnstone, D. W. 1971. The geology and geophysics of coastal Tanzania. - Natural Environment Research Council, Institute of Geological Sciences Geophysical Paper 6: VI + $101 \mathrm{pp}$.

Kjerfve, B. \& Magill, K. E. 1989. Geographic and hydrodynamic characteristics of shallow coastal lagoons. - Marine Geology 88: 187-199.

Kreuser, T. 1995. Rift to drift evolution in Permian-Jurassic basins of East Africa. In Lambiase, J. J. (ed.). Hydrocarbon Habitat in Rift Basins. Geological Society Special Publication 80: 297-315.

Lange, E. 1914. Die Brachiopoden, Lamellibranchiaten und Anneliden der Trigonia schwarzi-Schichten. - Archiv für Biontologie 3 (4): 187-289.

Lockley, M. 1991. Tracking dinosaurs: a new look at an ancient world. 238 pp., Cambridge University Press, Cambridge.

Maier, G. in press. African Dinosaurs Unearthed. The Tendaguru Expeditions. - Indiana University Press, Indianapolis.

Morkhoven, F. P. C. M. van 1963. Post-Palaeozoic Ostracoda, Vol. II. 478 pp., Elsevier Publishing Company, New York.

McIntosh, J. S. 1997. Sauropods. In Farlow, J. O. \& Brett-Surman, M. K. (eds). The Complete Dinosaur: 264-290, Indiana University Press, Bloomington and Indianapolis.

Moore, G. T., Hayashida, D. N., Ross, C. A. \& Jacobson, S. R. 1992. Paleoclimate of the Kimmeridgian/Tithonian (Late Jurassic) world: I. Results using a general circulation model. - Palaeogeography, Palaeoclimatology, Palaeoecology 93: 113-150.

Neale, J. W. 1988. Ostracods and palaeosalinity reconstruction. In De Decker, P., Colin, J.-P. \& Peypouquet, J. P (eds). Ostracoda in the Earth Sciences: 126-155, Elsevier Publishing Company, New York.

Parkinson, J. 1930. The dinosaur in East Africa. An account of the giant reptile beds of Tendaguru, Tanganyika Territory. $192 \mathrm{pp}$., Whitherby, London.

Patterson, C. 1966. British Wealden sharks. - Bulletin of the British Museum (Natural History), Geology 11: 283-350.

Paul, G. S. 1988. The brachiosaurs giants of the Morrison and Tendaguru with a description of a new subgenus, Giraffatitan, and a comparison of the worlds largest dinosaurs. Hunteria 2 (3): 1-14.

Powell, C. M., Roots, S. R. \& Veevers, J. J. 1988. Pre-breakup continental extension in East Gondwanaland and the early opening of the eastern Indian Ocean. - Tectonophysics 155: $261-283$.

Reck, H. 1925. Grabungen auf fossile Wirbeltiere in DeutschOstafrika. - Geologische Charakterbilder 31: 1-36.

1931. Die deutschostafrikanischen Flugsaurier. - Centralblatt für Mineralogie, Geologie und Paläontologie 1931 321-336.

Russell, D., Béland, P., McIntosh, J. S. 1980. Paleoecology of the dinosaurs of Tendaguru (Tanzania). - Mémoires de Société Geologique de France 59 (139): 169-175.

Sarjeant, W. A. S. \& Taylor, F. J. R. 1999. Dinoflagellates, fossil and modern: certain unresolved problems. - Grana 38: $186-192$

Schrank, E. 1999. Palynology of the dinosaur beds of Tendaguru (Tanzania) - preliminary results. - Mitteilungen aus dem Museum für Naturkunde Berlin, Geowissenschaftliche Reihe 2: 171-183.
Schrank, E. \& Mahmoud, M. S. 1998. Palynology (pollen, spores and dinoflagellates) and Cretaceous stratigraphy of the Dakhla Oasis, central Egypt. - Journal of African Earth Sciences 26: 167-193.

Schuchert, C. 1918. Age of the Morrison and East African Tendaguru formations. - Bulletin of the Geological Society of America 29: 245-280.

Schudack, M. 1999. Some charophytes from the Middle Dinosaur Member of the Tendaguru Formation (Upper Jurassic of Tanzania). - Mitteilungen aus dem Museum für Naturkunde Berlin, Geowissenschaftliche Reihe 2: 201-205.

Schudack, M. E. \& Schudack, U. 2002. Ostracods from the Middle Dinosaur Member of the Tendaguru Formation (Upper Jurassic of Tanzania). - Neues Jahrbuch für Geologie und Paläontologie, Monatshefte 2002 (6): 321-336.

Thies, D. 1995. Placoid scales (Chondrichthyes: Elasmobranchii) from the Late Jurassic (Kimmeridgian) of northern Germany. - Journal of Vertebrate Paleontology 15: $463-481$.

Thies, D. \& Reif, W.-E. 1985. Phylogeny and evolutionary ecology of Mesozoic Neoselachii. - Neues Jahrbuch für Geologie und Paläontologie, Abhandlungen 169 (3): 333-361.

TPDC 1995. Tanzania. Petroleum Exploration Potential. Tanzania Petroleum Development Corporation, 41 pp., Dar es Salaam.

Trouw, R. A. J. \& De Wit, M. J. 1999. Relation between the Gondwanide Orogen and contemporaneous intracratonic deformation. - Journal of African Earth Sciences 28: $203-213$.

Uhmann, A. 1996. Sedimentologische und fazielle Entwicklung in Jura und Kreide im Morondava Becken (SüdwestMadagaskar) - Untersuchungen zur Mikrofazies, Tongeologie und Schwermineralogie. 129 pp., VWB, Berlin.

Underwood, C. \& Rees, J. in press. Selachian faunas from the earliest Cretaceous Purbeck Group of Dorset, Southern England. - Special Papers in Palaeontology.

Underwood, C. \& Ward, D. J. in press. Environmental distribution of Bathonian (Middle Jurassic) neoselachians in southern England. In Tintori, A. \& Arratia, G. (eds). Mesozoic Fishes 3 - Systematics, Paleoenvironments and Biodiversity. Verlag Dr. F. Pfeil, München.

Unwin, D. \& Heinrich, W.-D. 1999. On a pterosaur jaw remain from the Late Jurassic of Tendaguru, East Africa. Mitteilungen aus dem Museum für Naturkunde Berlin, Geowissenschaftliche Reihe 2: 121-134.

Valdes, P. J. 1994. Atmospheric general circulation models of the Jurassic. In Allen, J. R. L, Hoskins, B. J., Sellwood, B. W., Spicer, R. A. \& Valdes, P. J. (eds). Palaeoclimates and their Modelling: With Special Reference to the Mesozoic Era: 109-118, Chapman \& Hall, London.

Valdes, P. J. \& Sellwood, B. W. 1992. A palaeoclimate model for the Kimmeridgian. - Palaeogeography, Palaeoclimatology, Palaeoecology 95: 47-72.

Virchow, H. 1919. Atlas und Epistropheus bei den Schildkröten. - Sitzungsberichte der Gesellschaft Naturforschender Freunde zu Berlin 1919: 303-332.

Visser, J. N. J. \& Praekelt, H. E. 1996. Subduction, megashear systems and Late Palaeozoic basin development in the African segment of Gondwana. - Geologische Rundschau 85: 632-646.

Watson, J. 1988. The Cheirolepidiaceac. In Beck, C. B. (ed.). Origin and Evolution of Gymnosperms: 382-447, Columbia University Press, New York.

Williamson, T. E., Kirkland, J. I. \& Lucas, S. G. 1993. Selachians from the Greenhorn Cyclothem ("Middle" Cretaceous: Cenomanian - Turonian), Black Mesa, Arizona, and the paleogeographic distribution of Late Cretaceous selachians. - Journal of Paleontology 67 (3): 447-474.

Zwierzycki, J. 1914. Die Cephalopodenfauna der TendaguruSchichten in Deutsch-Ostafrika. - Archiv für Biontologie 3 (4): $7-96$. 